\title{
Comparison of Helicobacter bilis-Associated Protein Expression in Huh7 Cells Harbouring HCV Replicon and in Replicon-Cured Cells
}

\author{
Arinze S. Okoli, ${ }^{1,2}$ Mark J. Raftery, ${ }^{3}$ and George L. Mendz ${ }^{4}$ \\ ${ }^{1}$ GenØK-Centre for Biosafety, Tromsø Science Park, 9294 Tromsø, Norway \\ ${ }^{2}$ School of Medical Sciences, The University of New South Wales, Sydney, NSW 2052, Australia \\ ${ }^{3}$ Bioanalytical Mass Spectrometry Facility, The University of New South Wales, Sydney, NSW 2052, Australia \\ ${ }^{4}$ School of Medicine, Sydney, The University of Notre Dame, New South Wales, Darlinghurst, NSW 2010, Australia \\ Correspondence should be addressed to Arinze S. Okoli, arinze.okoli@genok.no
}

Received 23 February 2012; Revised 5 June 2012; Accepted 5 June 2012

Academic Editor: Mario Reis Alvares-da-Silva

Copyright (๑) 2012 Arinze S. Okoli et al. This is an open access article distributed under the Creative Commons Attribution License, which permits unrestricted use, distribution, and reproduction in any medium, provided the original work is properly cited.

\begin{abstract}
Hepatocellular carcinoma (HCC) is one of the leading causes of cancer-related deaths worldwide. Hepatitis B or C infections are the main causes of $\mathrm{HCC}$ with hepatitis $\mathrm{C}$ being the major risk factor for liver cancer in the developed countries. Recently, complications with bacteria of the genus Helicobacter have been associated with HCV-induced HCC. To further understand the mechanisms leading to the development of HCC in the presence of HCV and/or Helicobacter spp., investigation of the differential protein expression in Huh7 cells harbouring HCV-replicon, and replicon cured-Huh7 cells cocultured with H. bilis was done employing two-dimensional gel electrophoresis and mass spectrometry. In the transfected-Huh7 cells exposed to sublethal inoculum densities of $H$. bilis, 53 different proteins were identified comprising of 28 upregulated and 16 downregulated proteins including 9 potential protein isoforms; in the cured Huh7 cells, 45 different proteins were identified including 33 upregulated, 8 downregulated and, 9 potential protein isoforms. $H$. bilis affected the modulation of proteins involved in different pathways of Huh7-derived cells physiology including proteins involved in the progression from dysplasia to neoplasm. The result also indicated that the response of the Huh7-derived cells to the presence of $H$. bilis depended on whether or not HCV replicon was present.
\end{abstract}

\section{Introduction}

Hepatocellular carcinoma (HCC) is a malignancy of the liver caused by cirrhosis, the scarring of liver tissues. Cirrhotic liver results from chronic inflammation generally attributed to chronic and persistent infections of the liver by Hepatitis $B$ virus (HBV) Hepatitis C virus (HCV), or alcohol abuse. Other carcinogens that have been associated with HCC include the Aspergillus aflatoxin $\mathrm{B} 1$, hemochromatosis, and fatty liver disease related to diabetes and obesity, but their frequencies of association with the liver cancer are lower than $\mathrm{HBV}$ or HCV.

Many of the chronic carriers of HBV or HCV do not develop cirrhotic liver, and only a subset of patients suffering from the viral-induced liver cirrhosis eventually progress to HCC, suggesting the existence of cofactors in hepatocarcinogenesis in the presence of HBV or HCV. For example, alcohol liver disease (ALD) has been documented as potentiating the development of the liver tumour in the presence of HBV or HCV [1], and syngergistic interactions between aflatoxin B1 and HBV have been reported in HCC [2]. In addition, information supports that coinfection with HBV and HCV increases the risk of HCC development over that with either viruses alone, and the increased risk is additive [3].

Recent information suggests the existence of bacteria cofactor in the progression of chronic viral hepatitis to cirrhosis and HCC. Bacteria DNA belonging to the Helicobacter genus have been increasingly identified in tissue specimen from patients suffering from HCV-induced HCC [4-7]. Further, in several HCV positive patients at different stages of the disease progression, Helicobacter DNA was found in $4.2 \%$ of the controls and $3.5 \%$ of the patients with noncirrhotic chronic hepatitis compared to $61-68 \%$ in cirrhotic liver and 
90\% in HCC tumoural tissue [8]. At different stages of the disease, the strength of association between the presence of Helicobacter DNA and the disease increased with severity of the cancer [8], suggesting that infections by Helicobacter spp. at some stage in the HCV-induced liver cirrhosis may contribute to the progression from dysplasia to neoplasia. The molecular mechanisms involved in the progression to cirrhosis and HCC in some patients suffering from HCVinduced hepatitis is still poorly understood, and the potential roles that Helicobacter spp. may play in HCC is largely unknown.

Helicobacter species cause persistent and chronic infections in their host cells where they induce strong inflammatory responses $[9,10]$. Given the role played by chronic inflammation in malignant diseases in general, and specifically in cirrhosis and HCC, and considering reports of greater degree of hepatic damage [11] and higher incidence of cirrhosis [12] in dual infection of both HBV and HCV, or infection of either virus in a background of ALD or aflatoxin B1 intoxication, the coinfection of HCV and Helicobacter spp. may have a role in the development of liver malignancy. These coinfections may be one of the triggers required for the progression from cirrhosis to cancer in HCV-induced HCC. The association between HCC and Helicobacter spp. is further enforced by the finding that $\mathrm{H}$. hepaticus induces chronic active hepatitis and HCC in A/JCr mice $[13,14]$, as well as the classification of $H$. pylori as a human carcinogen [15]. In this study, the effects of $H$. bilis on the proteome of Huh7 cells harbouring HCV replicon (transfected Huh7) and in replicon-cured Huh7 cells (cured Huh7 cells) were investigated.

Helicobacter bilis is a Gram-negative microaerophilic bacillus with urease, catalase, and oxidase activity, and a member of the enterohepatic Helicobacter species (EHS) that generally colonize the intestines, and livers of animals and birds. Helicobacter bilis colonizes the gall bladder, lower intestine and liver of mice where it causes chronic hepatitis and HCC $[16,17]$. Human hepatoma Huh7 is a well-differentiated liver epithelial cell line that is used commonly in the in vitro studies of the liver and its associated diseases [18]. In this study, Huh7 cells not cocultured with $H$. bilis served as controls; thus, comparative analysis between the experimental and control cell population will reveal the effects of the bacteria, notwithstanding that malignant transformation is already present in the hepatoma cells. The Huh7 transfection with Nneo3-5B (RG) is stable and permits the replication of HCV subgenomic replicon. The cured Huh7 is the rescued transfected Huh7 by treatment with interferon alpha (IFN$\alpha)$.

Global analyses of the proteome of cells grown under different conditions provide important information about the physiological processes that take place in the cells, the identification of new cancer biomarkers and disease-associated targets, and pathogenic processes. Proteomic analyses have been employed to study changes in protein expression related to carcinogenesis $[19,20]$. In the present study, two-dimensional polyacrylamide gel electrophoresis was employed to analyse the global protein expression profiles of cytosolic proteins obtained from the two Huh7-derived cell lines cocultured with and without $H$. bilis. Identities of differentially expressed proteins were determined by tandem mass spectrophotometry. Additionally, real-time polymerase chain reaction was employed to determine the differential expression of known HCC-related genes by the Huh7 cell lines in response to $H$. bilis.

\section{Materials and Methods}

2.1. Growth Conditions. The transfected and cured Huh7 cells were kind donations from Professor Peter White laboratory, School of Biotechnology and Biomolecular Sciences, the University of New South Wales, Sydney, Australia. The cells were transformed following the method of Inoue et al., 2007 [21], and the cured cells by treating the transfected cells with IFN- $\alpha$ using the method of Ikeda et al., 2002 [22]. The cells were maintained at $37^{\circ} \mathrm{C}$ in Dulbecco's Modified Eagle Medium (DMEM), containing $25 \mathrm{mM}$ D-glucose, and $4.0 \mathrm{mM}$ of Glutamax (L-alanyl-L-glutamine) as a substitute for L-glutamine (Invitrogen, Mulgrave, Vic, Australia), and supplemented with 10\% Neonatal Calf Serum (NCS) (Invitrogen; Australia). Prior to cocultures with $H$. bilis, cells were cultured in a $75 \mathrm{~cm}^{2}$ vented tissue culture flasks (Interpath Services; Caringbah, NSW, Australia) under an atmosphere of $5 \% \mathrm{CO}_{2}$ until $c a .50 \%$ confluency, and adapted for $6 \mathrm{~h}$ to the coculture media, which consisted of $9.25 \mathrm{~g} / \mathrm{L}$ Brain Heart Infusion (BHI) (Oxoid, Australia), 10\% (v/v) Horse Serum (Oxoid, Heilderberg, Vic, Australia), 10\% (v/v) NCS and 80\% (v/v) DMEM.

Helicobacter bilis strain ATCC 51630 was grown in Campylobacter Selective Agar (CSA), consisting of Blood Agar Base No. 2 (Oxoid; Australia), supplemented with 5\% (v/v) defibrinated horse blood (Oxoid, Australia). The media contained $2 \mu \mathrm{g} / \mathrm{mL}$ fungizone (Bristol-Myers Squibb; Sydney, NSW, Australia), $0.32 \mu \mathrm{g} / \mathrm{mL}$ polymixin B, $5 \mu \mathrm{g} / \mathrm{mL}$ trimethoprim, and $10 \mu \mathrm{g} / \mathrm{mL}$ vancomycin (Sigma; North Ryde, NSW, Australia). Bacterial cultures were incubated for $48 \mathrm{~h}$ at $37^{\circ} \mathrm{C}$ under the microaerobic conditions of $5 \% \mathrm{CO}_{2}, 5 \%$ $\mathrm{O}_{2}$ and $90 \% \mathrm{~N}_{2}$.

To study the effects of $H$. bilis on the transfected and cured Huh7 cells, bacteria were harvested from plates and grown for $6 \mathrm{~h}$ in the coculture media. Prior to cocultures with the human cells, the bacteria were washed in BHI broth and resuspended to a density of $\mathrm{OD}_{600} \sim 1.00$. Appropriate volumes of $H$. bilis were inoculated into the semiconfluent hepatoma cell cultures at densities of upto $10^{10} \mathrm{cfu} / \mathrm{mL}$. The cocultures were incubated at $37^{\circ} \mathrm{C}$ for $48 \mathrm{~h}$ under an atmosphere of $5 \% \mathrm{CO}_{2}, 5 \% \mathrm{O}_{2}$, and $90 \% \mathrm{~N}_{2}$. Control cultures, consisting of hepatoma cells in coculture media without bacteria were grown under the same conditions. Comparison of the growth of the hepatoma cells between microaerobic conditions and normal atmosphere of $5 \% \mathrm{CO}_{2}, 19 \% \mathrm{O}_{2}$, and $78 \% \mathrm{~N}_{2}$ was also carried out. After $48 \mathrm{~h}$ incubation, cell morphology was examined by inverted microscopy. The culture media was poured off from the vented flasks and cell monolayers were gently washed three times with sterile phosphate buffered saline $(\mathrm{pH}$ 7.6) to remove the bacteria from the cocultures containing $H$. bilis. To detach the cells, the flasks were flooded with $5 \mathrm{~mL}$ of Trypsin/EDTA 
$(0.13 \% / 0.03 \%)$, and incubated at $37^{\circ} \mathrm{C}$ in $5 \% \mathrm{CO}_{2}$ for approximately $20 \mathrm{~min}$ or until the cells were detached. The live/dead status of the Huh7 cells was determined by trypan blue staining to assess cell viability, and the number of live cells was counted using an improved neubauer cytometer. Bacterial growth was measured at $48 \mathrm{~h}$ and the morphology and purity of the cultures were determined by phase-contrast microscopy. Bacteria were grown on CSA plates to examine the creamy characteristics.

2.2. Preparation of Protein Samples. To determine differential protein expression, the Huh7-derived cells were grown in coculture media under a microaerobic atmosphere at $37^{\circ} \mathrm{C}$ without bacteria or with $10^{3} \mathrm{cfu} / \mathrm{mL} H$. bilis. After $48 \mathrm{~h}$ incubation, the transfected and cured Huh7 cells were detached, harvested by centrifugation at $1000 \times \mathrm{g}$ for $25 \mathrm{~min}$ at $4^{\circ} \mathrm{C}$, washed thrice with $30 \mathrm{~mL} 0.2 \mathrm{M}$ ice cold sucrose, mixed by pipetting, and centrifuged again at $1000 \times \mathrm{g}$ for $25 \mathrm{~min}$ at $4^{\circ} \mathrm{C}$. The resulting cell pellet was collected, resuspended in $1 \mathrm{~mL}$ TSU buffer, and disrupted on ice by sonication with a Branson digital sonifier (Branson Ultrasonics Corporation; Danbury, CT, USA) at amplitude of $30 \%$ for $15 \mathrm{~s}$ at a $5 \mathrm{~s}$ pulse and $5 \mathrm{~s}$ delay between pulses. This was repeated 15 times, and resulting suspension was centrifuged at $14000 \times \mathrm{g}$ for $20 \mathrm{~min}$ at $4^{\circ} \mathrm{C}$ to remove cell debris, the supernatant was collected and nucleic acids were removed by adding $10 \mu \mathrm{L}$ nuclease buffer and incubating for $20 \mathrm{~min}$ at $4^{\circ} \mathrm{C}$. Aliquots of the protein cell-free extracts were stored at $-80^{\circ} \mathrm{C}$ for a maximum of three months or until used for $2 \mathrm{D}$-gel electrophoresis.

The protein concentration of cell-free extracts was estimated by the bicinchoninic acid assay employing a microtitre protocol (Pierce, Rockford, IL, USA). Optical densities were measured at $595 \mathrm{~nm}$ using a Beckman Du 7500 spectrophotometer to determine the absorbances of the copper complexes in both samples and standards. The protein concentration of each sample was calculated based on a calibration curve constructed with known concentrations of BSA.

2.3. Two-Dimensional Gel Electrophoresis and Image Analyses. Two-dimensional polyacrylamide gel electrophoresis (2DPAGE) was performed as previously described [23] with some modifications. In the first dimension, an aliquot containing $150 \mu \mathrm{g}$ of protein was made up to a final volume of $250 \mu \mathrm{L}$ in freshly prepared rehydration buffer containing $8 \mathrm{M}$ urea, $100 \mathrm{mM}$ dithiothreitol (DTT), $65 \mathrm{mM} 3$-[(3-cholamidopropyl)-dimethyammonio]-1-propanesulfonate (CHAPS), $40 \mathrm{mM}$ Tris-HCL, $\mathrm{pH} 8.0$, and $10 \mu \mathrm{L}$ of $\mathrm{pH}$ 4-7 IPG buffer. Samples were centrifuged at $14000 \times \mathrm{g}$ at $4^{\circ} \mathrm{C}$ for $20 \mathrm{~min}$ to clarify the supernatants and were loaded onto an $11 \mathrm{~cm}$ immobiline dry strip pH 4-7 (Bio-Rad; Regents Park, NSW, Australia) in an immobiline tray. Isoelectric focusing was performed at $14^{\circ} \mathrm{C}$ using the IsoelectrIQ ${ }^{2}$ (Proteome Systems; North Ryde, NSW, Australia), programmed at $300 \mathrm{~V}$ fast voltage ramp for $4 \mathrm{~h}, 10,000 \mathrm{~V}$ linear voltage ramp for $8 \mathrm{~h}$, and $10,000 \mathrm{~V}$ fast/linear voltage ramp for $12 \mathrm{~h}$, or until $120,000 \mathrm{Vh}$ were reached. Following isoelectric focusing, strips were equilibrated in two buffers containing $6 \mathrm{M}$ urea, $20 \%(\mathrm{v} / \mathrm{v})$ glycerol, $2 \%(\mathrm{w} / \mathrm{v})$ SDS, $375 \mathrm{mM}$ Tris- $\mathrm{HCl}$; the first with $130 \mathrm{mM}$ DTT and the second with $135 \mathrm{mM}$ iodoacetamide (IA).

In the second dimension, sodium dodecyl sulphate-polyacrylamide gel electrophoresis (SDS-PAGE) was performed on criterion system precast $12.5 \%$ acrylamide gels (Bio-Rad, Australia) at $14^{\circ} \mathrm{C}$ and $50 \mathrm{~V}$ for $1 \mathrm{~h}$, followed by $64 \mathrm{~mA}$ for $2 \mathrm{~h}$ or until the bromphenol blue dye front reached the bottom of the gels. Gels were fixed separately in $100 \mathrm{~mL}$ of fixing solution ( $50 \% \mathrm{v} / \mathrm{v}$ methanol, $10 \% \mathrm{v} / \mathrm{v}$ acetic acid) with gentle shaking for a minimum of $0.5 \mathrm{~h}$, stained employing a silver staining method [24], and imaged using a Umax PowerLook1000 flatbed scanner (FujiFilm; Tokyo, Japan). For comparative gel-image analysis, data were acquired and analyzed using the Z3 software package (Compugen; Jamesburg, NJ, USA). Statistical analyses (Student's $t$-test, 95\% confidence interval) were performed on three gels from each growth conditions (experimental versus control) to determine the differential spot intensities between both conditions. In the analyses, a gel from cells grown without bacteria served as the reference gel; master gels were compiled from three gels of each growth condition, and were compared to determine the relative intensities of each protein spot.

2.4. Mass Spectrometry Identification of Proteins. Protein spots showing two-fold or more differences in intensity between both experimental conditions were cut out of the gels and washed twice for $10 \mathrm{~min}$ in $200 \mu \mathrm{L}$ of $100 \mathrm{mM}$ $\mathrm{NH}_{4} \mathrm{HCO}_{3}$, reduced at $37^{\circ} \mathrm{C}$ for $1 \mathrm{~h}$ with $50 \mu \mathrm{L}$ of $10 \mathrm{mM}$ DTT, alkylated for $1 \mathrm{~h}$ in $50 \mu \mathrm{L}$ of $10 \mathrm{mM}$ IA, washed for 10 min with $0.2 \mathrm{~mL}$ of $10 \mathrm{mM} \mathrm{NH} \mathrm{HCO}_{3}$, dehydrated in acetonitrile, and trypsin-digested with $10 \mathrm{ng} / \mu \mathrm{L}$ of trypsin (Promega; Annandale, NSW, Australia). After digestion for $14 \mathrm{~h}$ at $37^{\circ} \mathrm{C}$, peptides were extracted by washing the gel slice for $15 \mathrm{~min}$ with $25 \mu \mathrm{L} 1 \%$ formic acid, followed by dehydration in acetonitrile. Digests were then dried in vacuo, resuspended in $10 \mu \mathrm{L} 1 \%$ formic acid and separated by nanoLC using an Ultimate/Famos/Switchos system (LC Packings, Dionex; Lane Cove, NSW, Australia). Samples $(5 \mu \mathrm{L})$ were loaded on to a C18 precolumn (Micron; $500 \mu \mathrm{m} \times 2 \mathrm{~mm}$ ) with buffer A (98\% $\mathrm{H}_{2} \mathrm{O}, 2 \% \mathrm{CH}_{3} \mathrm{CN}, 0.1 \%$ formic acid) and eluted at $25 \mu \mathrm{L} / \mathrm{min}$. After a $4 \mathrm{~min}$ wash, the flow was switched into line with a C18 RP analytical column (PEPMAP; $75 \mathrm{~lm} \times 15 \mathrm{~cm}$ ) and eluted for $30 \mathrm{~min}$ using buffer A at $200 \mu \mathrm{L} / \mathrm{min}$. The nano-electrospray needle was positioned $\sim 1 \mathrm{~cm}$ from the orifice of an API QStar Pulsar tandem mass spectrometer (ABI; Foster City, CA, USA). The QStar instrument was operated in information-dependent acquisition mode. A time-of-flight mass spectrometry survey scan was acquired $(\mathrm{m} / \mathrm{z} 350-1700,0.5 \mathrm{~s})$, and the two largest precursors (counts $>10$ ) were selected sequentially by Q1 for tandem MS analysis (m/z 50-2000, $2.5 \mathrm{~s}$ ). A processing script generated data suitable for submission to database search programs. Collision induced dissociation spectra were analysed using the Mascot MS/MS ion search engine (Matrix Sciences; Boston. MA, USA) with the following parameters: trypsin digestion allowing up to one missed cleavage, oxidation of methionine, peptide tolerance of $0.25 \mathrm{Da}$, and MS/MS tolerance of 0.2 Da. Searches were performed on the National 
Centre for Biotechnology Information nonredundant (NCBI nr) database.

2.5. Real Time Polymerase Chain Reaction ( $q R T-P C R)$. Total RNA was extracted from transfected- and cured Huh7 cells using the TRIzol reagent (Invitrogen, Australia) according to the manufacturer's instructions. The optical density measured at $260 \mathrm{~nm}$ was employed to determine RNA concentrations; and RNA purity was verified by measuring the optical density ratios, $\mathrm{OD}_{260} / \mathrm{OD}_{280}$ and $\mathrm{OD}_{260} / \mathrm{OD}_{230}$ using a NanoDrop ND-1000 spectrophotometer (Biolab; Mulgrave, VIC, Australia). RNA samples with $\mathrm{OD}_{260} / \mathrm{OD}_{280}<1.8$ or $\mathrm{OD}_{260} / \mathrm{OD}_{230}<1.9$ were further purified by overnight ethanol precipitation at $-20^{\circ} \mathrm{C}$ in $3 \mathrm{M}$ sodium acetate $(\mathrm{pH}$ 5.2). Purified RNA pellets were washed once with $80 \%$ ethanol and resuspended in DEPC- $\mathrm{H}_{2} \mathrm{O}$. RNA samples were stored at $-80^{\circ} \mathrm{C}$ for three months or until used.

Specific primers were designed based on the sequences published in the Human Genome available on the NCBI database; and employing the primer3 algorithm [http:// www.genome.wi.mit.edu/genome_software/other/primer3] .html]. The properties of the primers were: melting temperatures between $60-63^{\circ} \mathrm{C}$, length $19-23 \mathrm{bp}$, G-C content $50-55 \%$, and expected size of the product $200-210 \mathrm{bp}$. The primer sequences used in this study is available on request.

To study the differential expression of genes reported to be associated with HCC, total RNA extracted from the Huh7derived cells exposed to $H$. bilis was reverse-transcribed to cDNA using SuperScript III First-strand SuperMix kit (Invitrogen, Australia). Quantitative real-time PCR analyses were performed in triplicate using a Corbett Research Rotor Gene RG-3000 thermal cycler (Corbett Life Science; Sydney, NSW, Australia), employing the SYBR GreenER qPCR universal supermix according to the manufacturer's instructions (Invitrogen, Australia). Each reaction was performed in an individual tube in a seventy-two tube strips, containing $12.5 \mu \mathrm{L}$ supermix, $1.0 \mu \mathrm{L}$ of $100 \mathrm{ng} / \mu \mathrm{L}$ forward primer, $1.0 \mu \mathrm{L}$ of $100 \mathrm{ng} / \mu \mathrm{L}$ reverse primer, $1.0 \mu \mathrm{L}$ of $100 \mathrm{ng} / \mu \mathrm{L}$ of $\mathrm{cDNA}$, and DEPC-treated water to a total volume of $25 \mu \mathrm{L}$. As controls, reactions were also run in the absence of template cDNA to detect any contamination for each primer set. Conditions for the qRT-PCR were $2 \mathrm{~min}$ at $50^{\circ} \mathrm{C}, 10 \mathrm{~min}$ at $95^{\circ} \mathrm{C}$ and 40 cycles each consisting of $15 \mathrm{~s}$ at $95^{\circ} \mathrm{C}$, and $40 \mathrm{~s}$ at $60^{\circ} \mathrm{C}$, and acquiring flourescence at $76^{\circ} \mathrm{C}$ for $15 \mathrm{~s}$. At the completion of the PCR run, the temperature was increased from $72^{\circ} \mathrm{C}$ to $95^{\circ} \mathrm{C}$ for $115 \mathrm{~s}$; the flourescence was measured continuously to construct melting curves. The relative expression of each target gene was normalized to the glyceraldehyde 3-phosphate dehydrogenase (GAPDH) gene using the method described by [25]. Briefly, the crossing points (CP) for each target gene were normalized to the geometric mean CP of the house keeping gene employing the following expression:

$$
\text { Ratio }=\frac{\left(E_{\text {Target }}\right)^{\Delta c t \text { Target(Control-Sample) }}}{\left(E_{\text {Reference }}\right)^{\Delta c t \text { Reference(Control-Sample) }}},
$$

where $E$ is the amplification efficiencies of target and reference genes, assumed in this study to be 2 for all

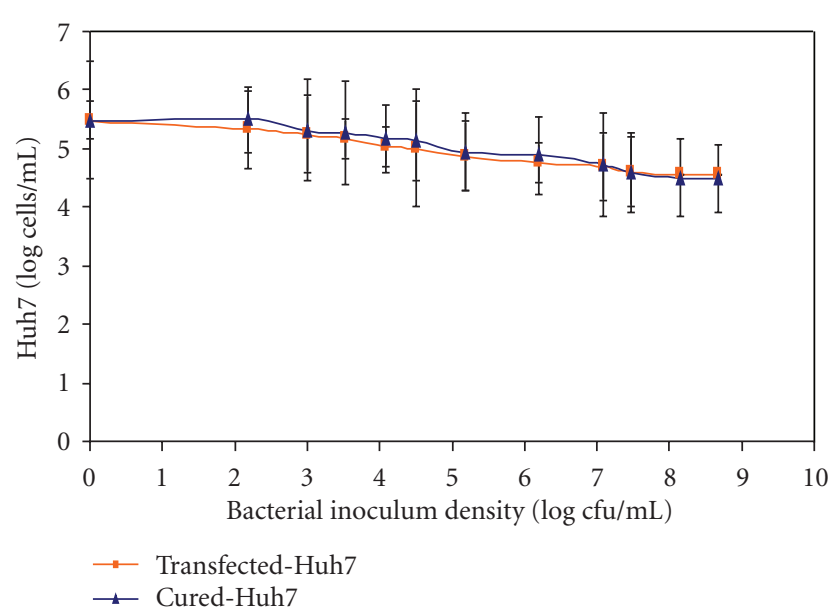

FIGURE 1: Growth of transfected- and cured Huh7 cells in cocultures with $H$. bilis at different inoculum densities. The initial number of Huh7 cells determined by the improved Neuber cytometer after staining with trypan blue was ca. $10^{5.5}$ cells $/ \mathrm{ml}$. The number of viable Huh7 cells counted after $48 \mathrm{~h}$ in cocultures with $H$. bilis are shown in the figure. The values represent the mean count of Huh7 cells from three independent experiments.

genes [26], and Ct is the comparative threshold cycle. The control/sample values were obtained with template cDNA from transfected- and cured Huh7 cells without bacteria and those exposed to sublethal $H$. bilis density of $10^{3} \mathrm{cfu} / \mathrm{mL}$.

\section{Results and Discussion}

3.1. Growth of Huh7-Derived Cell Lines in CoCultures with $H$. bilis. In the transfected- and cured Huh7 cells cocultured with $H$. bilis, hummingbird morphology was observed at bacterial densities of $10^{3} \mathrm{cfu} / \mathrm{mL}$ and higher. The results also revealed no significant $(P>0.05)$ decline in cell proliferation between the transfected and cured Huh7 cells (Figure 1), suggesting that neither the presence of the HCV-replicon nor its inactivation by IFN- $\alpha$ treatment affected differently the morphology and growth-response of the liver cells to the stress exerted by the presence of $H$. bilis. This phenomenon was similar to that observed in the parent Huh7 cells described previously (manuscript submitted elsewhere). This study did not investigate the response of the hepatoma cells to IFN- $\alpha$ treatment in the presence of $H$. bilis although it is acknowledged that the cured cells could also present the effects of IFN- $\alpha$.

3.2. Differential Expression of Proteins by the Transfected-and Cured Huh7 Cell Lines in response to H. bilis. Total proteins from transfected- and cured Huh7 cells cultured in the presence and absence of $H$. bilis were extracted, purified, and separated in two dimensions employing a $\mathrm{pH}$ gradient of 4-7 for the first dimension, and an 11.5\% SDS acrylamide gel in the second dimension. The intensities of protein spots from transfected- and cured Huh7 cells grown in the presence and absence of $H$. bilis were determined. Spots with differential intensities equal to or greater than 2-fold 


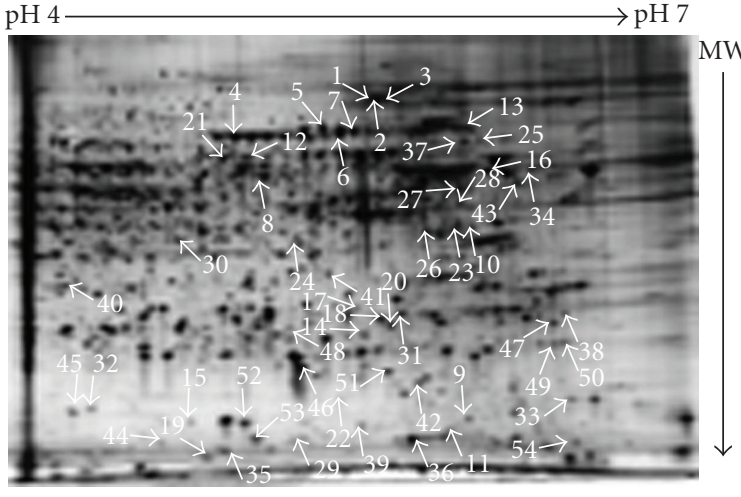

Transfected-Huh7

(a)

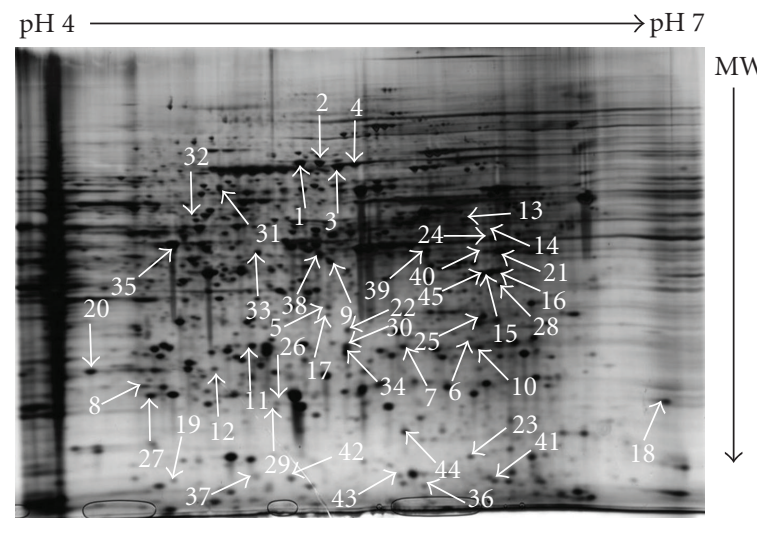

Cured-Huh7

(c)

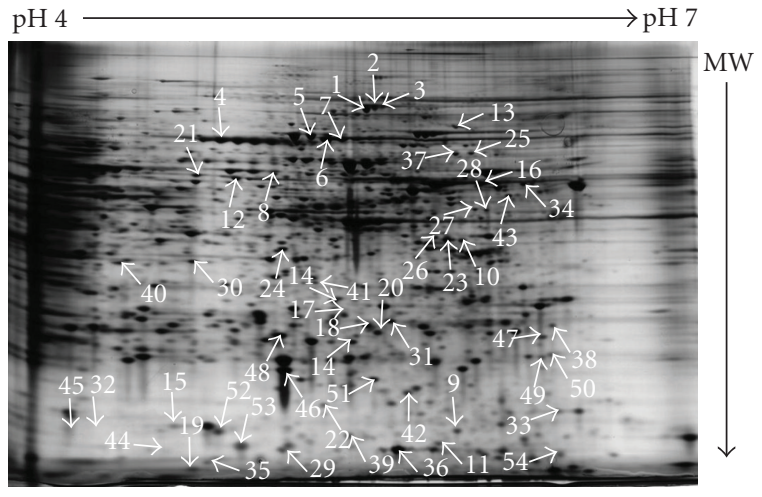

Transfected-Huh7/H. bilis

(b)

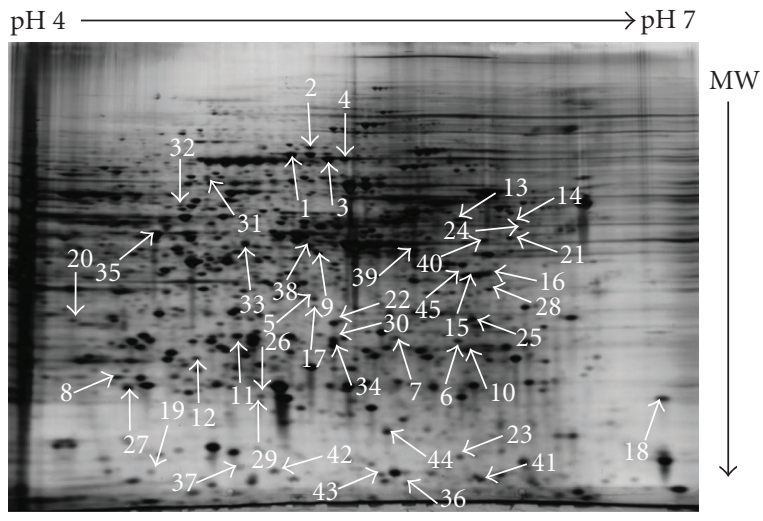

Cured-Huh7/H. bilis

(d)

Figure 2: 2D-PAGE gels showing spots of soluble proteins of transfected and cured Huh7 cells in the pI 4-7 range. Gels (a) and (b) correspond to proteins of transfected Huh7 cells, gels (c) and (d) correspond to proteins of cured Huh7 cells. Cells were incubated in the presence of an initial $H$. bilis inoculum of approximately $10^{3} \mathrm{cfu} / \mathrm{mL}$. Protein spots in gels were visualised by silver staining. The spot intensities from triplicate gels of three independent experiments were determined using the Z3 computational software. Spots corresponding to proteins differentially expressed are indicated on the figure.

between cultures grown with and without bacteria were considered to be up or downregulated, and identified by LCMS/MS. Figure 2 shows four reference 2D-gels from each growth condition obtained from at least three independent experiments. In the transfected Huh7 cells exposed to sublethal inoculum densities of $H$. bilis, a total of 53 different proteins were identified comprising of 28 upregulated and 16 downregulated proteins, including 9 potential protein isoforms; in the cured Huh7 cells/H. bilis cocultures, 45 different proteins were differentially expressed including 33 upregulated, 8 downregulated, and 9 potential protein isoforms (Table 1). The potential protein isoforms consist of proteins that were identified in the same spots as highlighted in Table 1.

\subsection{Biological Functions of the Modulated Proteins of} Transfected-and Cured Huh7 Cell Lines in CoCultures with H. bilis. The identified proteins were related to several important biological functions, namely, regulation of cell proliferation and structure, metabolism and biosynthesis, protein translation and modification, regulation of transcription, stress response, signal transduction and transport, and tumour-related proteins (Table 1).

3.4. Metabolic Enzymes. Hepatocellular carcinoma often exhibits aberrant expression of metabolic enzymes. Various studies have shown perturbations of host metabolism during HCV infection [27, 28]. For example, [27] showed perturbations in glycolysis, the pentose phosphate pathway, and the citric acid cycle during in vitro HCV infection of Huh7.5 cells. In the present study, both transfected- and cured Huh7 cells modulated proteins of various metabolic pathways in response to $H$. bilis. The glycolytic enzymes enolase (ENO) and triosephosphate isomerase (TIM) were upregulated in the transfected Huh7 cells, and the cured Huh7 cell line also upregulated TIM, suggesting an upregulation of glycolysis by both types of cells in response to $H$. bilis. Upregulation of glycolysis would provide energy required by the hepatocytes to resist the stress exerted by $H$. bilis. Increased glycolysis is consistent with the upregulation of other enzymes involved in energy production observed in this study, namely, ATP5B and ATP5H in the transfected Huh7 cells; and ATP5B in 


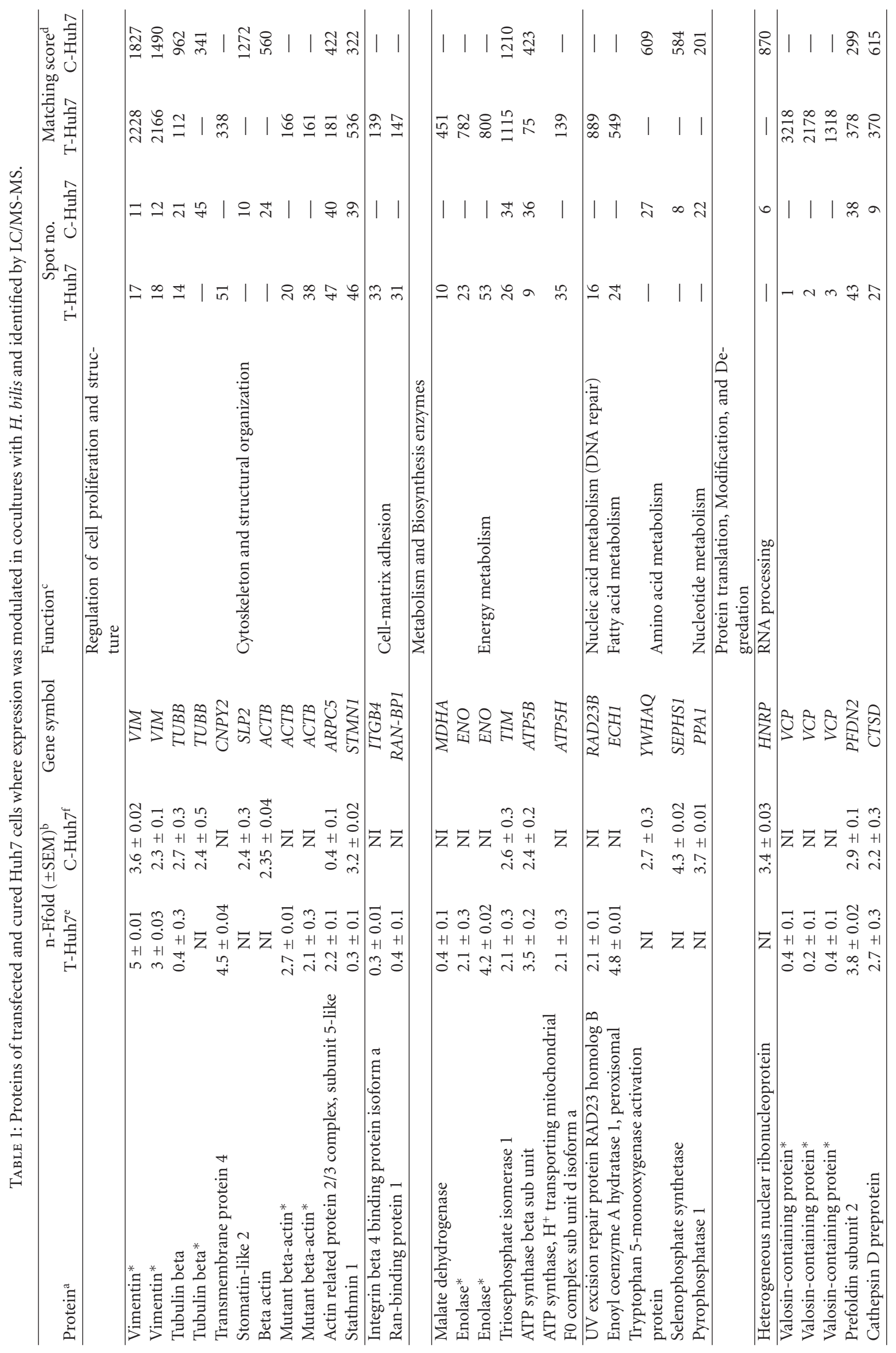




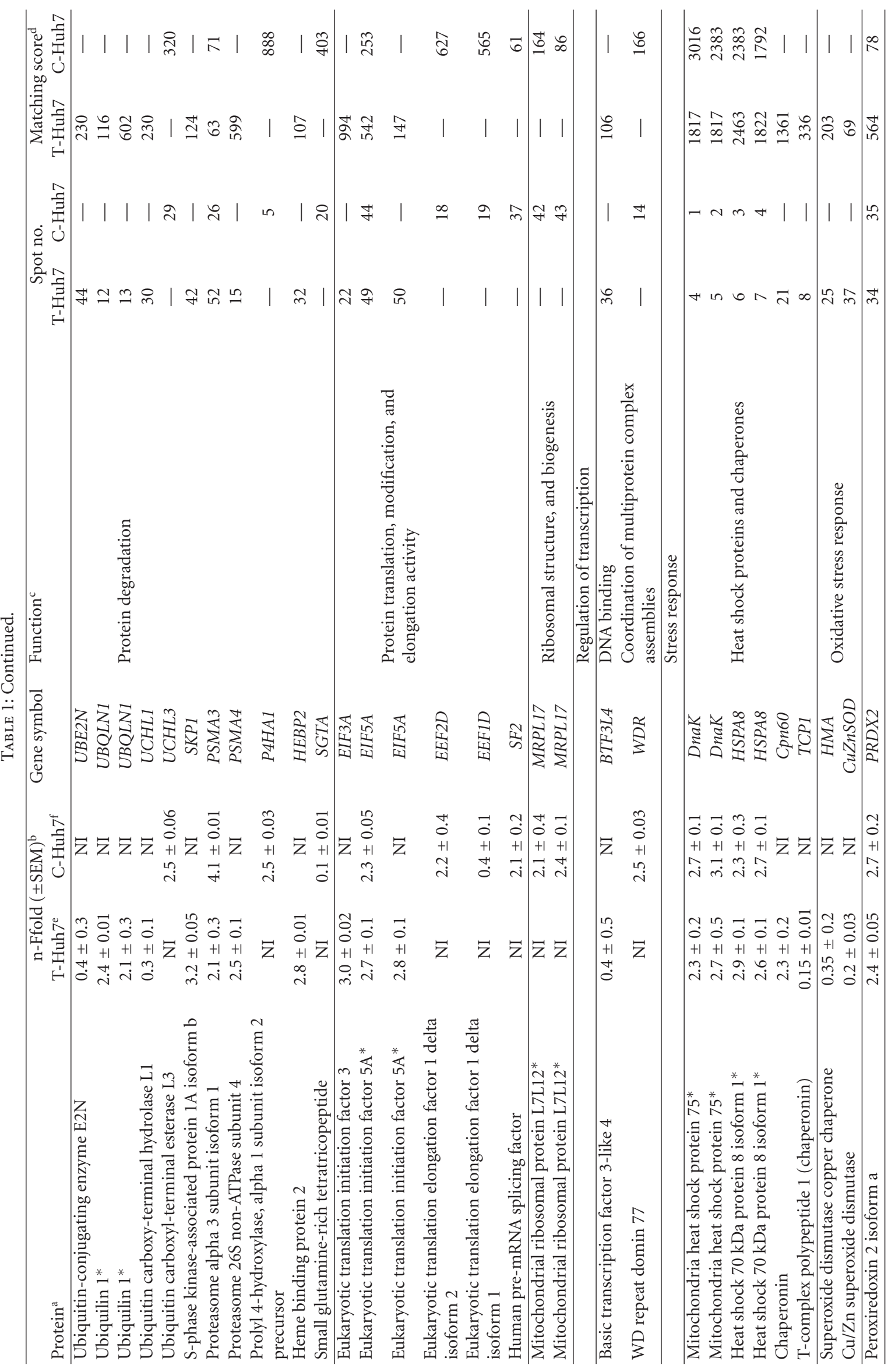




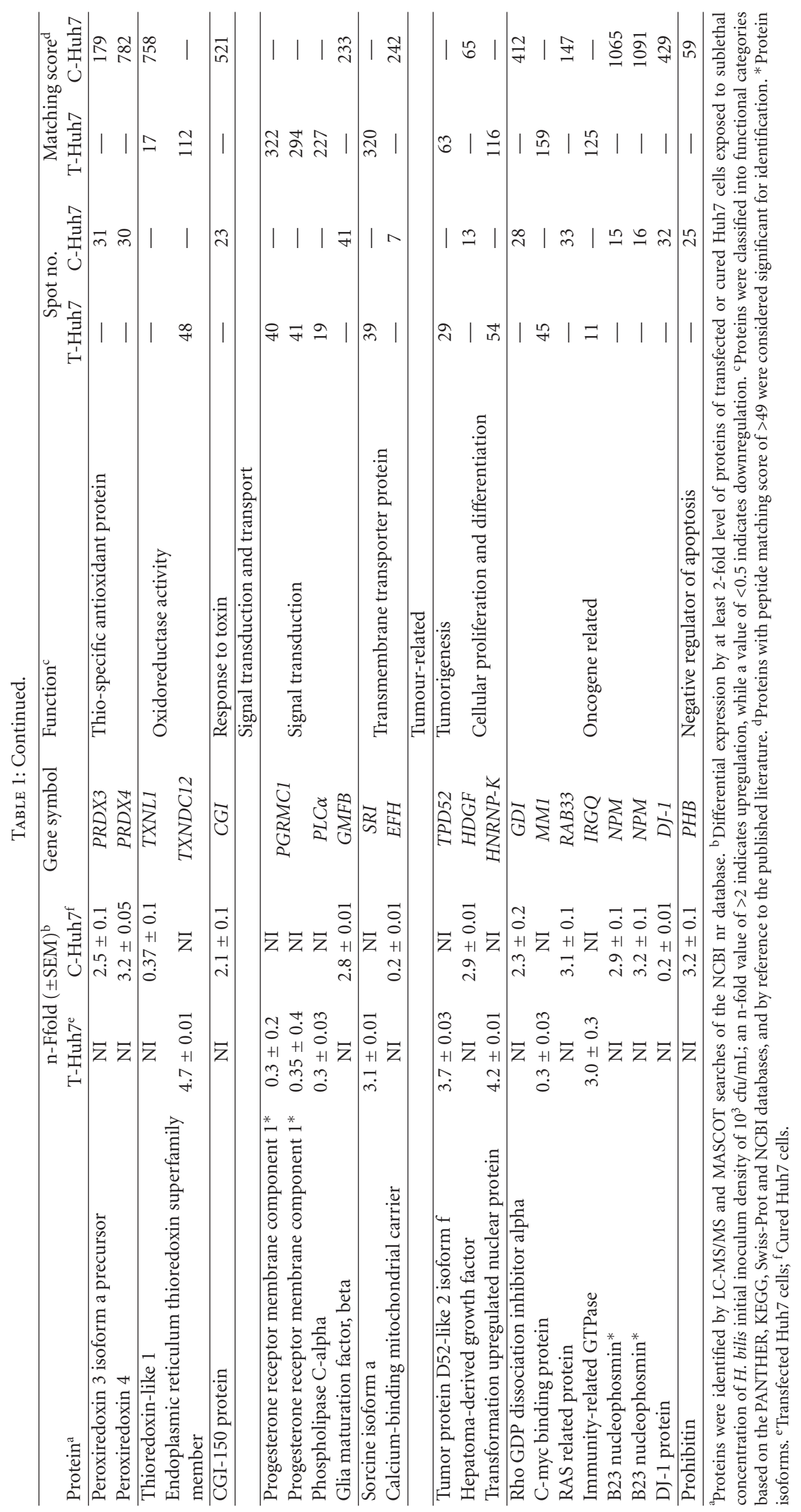


the cured Huh7 cells. Similar upregulation of energy producing enzymes was observed in our previous study with the parent Huh7 cells to H. bilis, thus indicating a common response to $\mathrm{H}$. bilis whether or not $\mathrm{HCV}$ replicon is present in the cell.

The enoyl coenzyme A hydratase 1, ECH1, participates in fatty acid, propanoate, and tryptophan metabolism. The enzyme was upregulated in the transfected Huh7 cells but was not found among the modulated proteins of the cured Huh7 cells in cocultures with $H$. bilis. Upregulation of ECH1 could increase the biosynthesis of fatty acid metabolic intermediates required for the maintenance of cell membrane stability under the stress exerted by $H$. bilis. It also suggested mitochondrial stress and hepatic lipid oxidation, both of which have been linked to liver cirrhosis [29]. Among the regulated proteins of the cured Huh7 cells cocultured with $H$. bilis, was the tryptophan 5-monooxygenase activation protein YWHAQ, that participates in signal transduction.

Several of the metabolic enzymes identified in the transfected Huh7 cells in response to $H$. bilis presence were not identified in the cured Huh7 cells from which the replicon has been eliminated by IFN- $\alpha$ treatment or in the previously studied parental Huh7 cells. This indicates a synergy between the activities of the replicon and $\mathrm{H}$. bilis on the metabolic pathway of the hepatoma cells. Also, the difference in the modulated metabolic proteins between the parental and cured Huh7 cells suggests the effect of IFN- $\alpha$ treatment on the cured cells and/or a permanent effect of the virus on the cells such that it responds $H$. bilis differently from the parental cells; a future study in which an IFN- $\alpha$ Huh7 cell population is included as a control would serve to resolve this. Nonetheless, this result is in concordance with the study of [30] which showed differences in the response to HCV infection of naïve, transfected and cured Huh7 cells.

3.5. Stress Response Proteins. Similarity in the upregulation of the heat shock proteins and chaperones was observed in both transfected and cured Huh7 cells in response to $H$. bilis. Similar upregulation in both cells was observed with the thio-specific antioxidant proteins, although peroxiredoxin 3 isoform precursor and peroxiredoxin 4 were identified only in the cured cells. Oxidative stress response proteins were downregulated in the transfected cells, but were not identified among the regulated proteins of the cured Huh7 cells. Notably, the 2 thioredoxin proteins identified were modulated differently in both cells: thioredoxin 1 was downregulated in the cured cells while in the transfected cells, the endoplasmic reticulum thioredoxin superfamily member protein was upregulated.

The data indicated that $H$. bilis exerted stress on the mitochondria resulting in the regulation of mitochondriallocalised DNAK, CPN60, PRXD3, and SOD proteins. The upregulation of the endoplasmic-reticulum- (ER-) specific TXNDC12 suggested also that an ER stress was exerted on the transfected Huh7 cells. The differences in the modulation between the transfected- and cured Huh7 cells of stress response proteins indicated that the presence of the HCVreplicon affected the molecular response of the hepatocytes to H. bilis.
This difference in the responses to $H$. bilis of the two cells not containing HCV replicon (parent Huh7 and cured Huh7 cells) suggested a permanent alteration of some cellular pathways by the virus or by the treatment with IFN- $\alpha$. Generally, during the infection of hepatocytes by HCV, the lipid peroxidation and ROS generated by the hepatic inflammation that is induced due to the release of proinflammatory cytokines [31] could cause breaks in cellular DNA or mutations in different genes [32-34]. These mutations may result in permanent changes in some cellular pathways even when the virus has been inactivated. Similarly, treatment with IFN- $\alpha$ could lead to changes in the Huh7 cells; for example, changes in the functions of cellular factors were induced in Huh7 cells following exposure to IFN- $\alpha$ [35]; also, alterations in some signaling pathways of hepatoma cells treated with IFN- $\alpha$ have been reported [36]. Thus, the observed differences in the molecular response of the parent and the cured Huh7 cells to H. bilis could be the result of changes in the cells caused by the alterations of cellular pathways by the virus and/or by exposure to IFN- $\alpha$.

3.6. Protein Translation, Modification, and Degradation. This category covers proteins that participate in the synthesis, translation, proper folding of other proteins, and degradation of misfolded proteins. Given the number and pattern of modulation of identified proteins in this category compared to other categories (overall total number of modulated proteins $=21$. Total from transfected cells $=12$ : upregulated $=9$, downregulated $=3$. Total from cured cells $=13$ : upregulated $=11$ and downregulated $=2$ ), it is reasonable to infer that the presence of $H$. bilis caused major perturbation in the protein translation, modification, and degradation machineries of the cell. This becomes more apparent when compared with our data on the effect of the bacterium on the parent Huh7 cells in which all 7 modulated proteins were downregulated (data submitted elsewhere).

The upregulation of elongation initiation factor EIFA in the transfected cells and EIF5A in both the transfectedand cured Huh7 cells suggested overall increase in protein synthesis in both cells. The upregulation in both cell types of the prefolding subunit 2, PFDN2, which also participates in protein production by ensuring that newly synthesized polypeptides fold correctly through binding and stabilizing them, supports the notion that protein synthesis was upregulated by both cells in response to $H$. bilis. In the cured Huh7 cells, the human pre-mRNA splicing factor, $\mathrm{SF} 2$, was also upregulated, but the heterogeneous nuclear ribonucleoprotein C (HNRP) and mitochondrial ribosomal protein, MRPL17, which also functions in the stabilization of newly synthesized polypeptides, were downregulated. Thus, the downregulation of both HNRP and MRPL17 is counter intuitive to the notion of increased protein synthesis of the cells in response to $H$. bilis. Besides the functions of HNRPC and MRPL17 in stabilizing newly synthesized polypeptides and ensuring proper folding of newly translated proteins [37], both proteins are also involved in cellular apoptotic pathways [37-40]. Their downregulation would therefore affect the normal programmed death of stressed and diseased cells, which could induce cell changes leading 
to the emergence of mutated cells. Also counter intuitive to increased protein production in response to the bacteria was the downregulation of the translation elongation factors, EEF1D and EEF2D, in the cured Huh7 cells indicating that the presence of the bacterium affected the normal protein expression of the cell.

The effect of the bacterium in the normal protein expression of the cells could result in accumulation of misfolded and/or mutated proteins. This could explain the apparent activation by the cells of the the ubiquitin system, which is primarily involved in protein degradation [41]. Proteins destined for degradation are tagged with the ubiquitin protein through a series of enzymatic steps initiated by an ubiquitin-activating enzyme E1. Following activation, the ubiquitin is transferred to the ubiquitinconjugating enzyme E2, and finally to a target protein in a process facilitated by the E3 ligase. Specific selection for targets is accomplished by E2 and E3 proteins. UBE2N is a human mono-ubiquitinated form of ubiquitin-conjugating enzyme which promotes the polyubiquitination of specific targets that modulate the activity of various cellular processes including DNA repair, mitotic progression, and nuclear factor-kappaB signaling [42]. Among the various types of E3 proteins SKP1 is a component of the SCF (SKP11/Culin/Fbox protein) ligases. Ubiquilins function as shuttle vectors to deliver ubiquitinated proteins to the proteasomes in the endoplasmic reticulum for degradation. In transfected Huh7 cells, the upregulation of the E3 ligase SKP1, the ubiquilin UBQLN1, and the proteasome proteins PSMA2, PSMA3 and PSMA4 indicated an activation of the ubiquitin system, although UBE2N was downregulated suggesting a downregulation of the ubiquitin system at the point of ubiquitin conjugation. However, other conjugases such as UBE2D1, which are specifically associated with the SCF family of ligases, could salvage the system at the point of ubiquitin conjugation.

Further evidence of the bacteria effect on the ubiquitin pathway was the downregulation of ubiquitin carboxyl-terminal hydrolase enzymes, UCHL1, and UCHL3 in both transfected and cured cells. In addition, upregulation in both cells of cathepsin D, (CTSD), an apoptotic regulatory enzyme [43], whose upregulation has also been associated with HCC [44], indicate the perturbation of the apoptotic pathway and suggests a potential carcinogenic effects of the bacterium.

Compared to the cured Huh7 cells, the transfected Huh7 cells modulated the expression of a larger number of proteins involved in protein degradation pathways, probably reflecting that $H$. bilis induced the generation of more abnormal proteins in the latter cells. This would suggest an exertion of a greater stress by the bacterium on the transfected Huh7 cells relative to the cured Huh7 cells. Similarly to the cured Huh7 cells, the parent Huh7 cells modulated fewer proteins that participate in protein degradation pathways (Data not shown). Hence, in comparison, $H$. bilis appeared to have exerted greater stress on the transfected Huh7 cells.

3.7. Cell Proliferation and Structure. Dysregulation of cell proliferation represents a protumorigenic principle in human hepatocarcinogenesis. The transfected- and cured
Huh7 cells modulated a good number of proteins involved in the regulation of cell proliferation and structure (Table 1). Vimentin (VIM) is a cytoplasmic intermediate filament characteristic of mesenchymal cells usually not expressed in epithelial cells [45], but was upregulated by both the transfected- and cured Huh7 cell lines in response to $H$. bilis. Gilles and co-workers showed that the atypical expression of VIM in epithelial cancer cells might be associated with local invasiveness and metastasis potential [46]. The overexpression of VIM and its relation to tumor metastasis have been reported in several carcinomas [47-49], and its expression in the various cancer cells was essential to the successive shape change through the interaction with actin and other intermediate filaments [50]. Thus, the upregulation of VIM by both the transfected- and cured Huh7 cells may be correlated to the hummingbird morphology, and also indicates a carcinogenic effect of $H$. bilis on the cell lines.

Related to the regulation of cell structure, cytoskeletal proteins that control microfilament and microtubules were found among the modulated proteins of the transfectedand cured Huh7 cells. In both cell lines, beta-actin (ACTB) was upregulated. The highly conserved ubiquitous ACTB is regarded as a housekeeping gene involved in the formation of filaments that are a major component of the cytoskeleton, and participates in cell motility, structure, and integrity. Its upregulation by both Huh7 cells therefore shows that $H$. bilis affected basic cellular functions including cell morphogenesis. Upregulation of ACTB has also been reported in HCV-induced HCC [51] as well as in other cancer types $[52,53]$, suggesting a carcinogenic effect of $H$. bilis. An actin related protein $2 / 3$ complex subunit 5 (ARPC5) was also upregulated in the transfected Huh7 cells but was downregulated by the cured Huh7 cells, and tubulin beta (TUBB) was downregulated in the transfected Huh7 cells but was upregulated in the cured Huh7 cells. The modulation of cytoskeletal proteins by the transfected- and cured Huh7 cells suggested a response to cytoskeletal stress that could disrupt the normal functioning of Huh7 cells and may result in the cells losing their ability to regulate shape and volume. This stress can promote abnormalities in cell morphology that lead to cell death, and help to explain the observed hummingbird morphology and decrease in cell proliferation observed in the Huh7-derived cell lines cocultured with $H$. bilis.

Further, the modulation of TUBB indicated that the bacterium affected gap junction formations in both Huh7derived cell lines. Gap junctions are connections between cytoplasm of two adjacent cells that make exchange of molecules and ions possible [54], and these are regulated by TUBB. In addition, TUBB is the building block of microtubules, which form structural cytoskeleton. Hence its up and downregulation in the cured- and transfected Huh7 cells respectively suggested a structural change in the presence of $H$. bilis. Similarly, modulation of ARPC5, a complex of the actin-related proteins ARP2 and ARP3 able to regulate actin polymerization [55], is another molecular event that could contribute to the change in morphology of the hepatoma cells in response to $H$. bilis. 
3.8. Tumour-Related Proteins. Proteins that are associated with tumourigenesis were identified among those regulated in both the transfected- and cured Huh7 cells cocultured with $H$. bilis. In the former, transformation upregulated nuclear protein (HNRNP-K) was upregulated, together with tumour protein D52-like 2 isoform $\mathrm{f}$ (TPD52); C-MYC binding protein (MM1) was however downregulated in response to $H$. bilis. In cured Huh7 cells, hepatoma-derived growth factor (HDGF), rho GDP dissociation inhibitor alpha (GDI) and prohibitin (PHB) were upregulated, but B23 nucleophosmin (NPM) and DJ-1 protein (DJ-1) were downregulated in response to $H$. bilis.

HNRNP-K is highly upregulated in transformed cells. Its specific role in cell transformation is still largely unclear, but it is thought to be involved in cell cycle progression [56]. TPD52-like proteins are small coiled-coil motif bearing proteins originally identified through their elevated expression level in human breast carcinoma. It plays a role in calciummediated signal transduction and cell proliferation [57, 58]. TPD52 also regulates mitosis and facilitates membrane tethering and fusion through binding integral membrane and membrane-associated proteins, and its deregulated expression may affect adversely cell division and proliferation [59]. The protein is overexpressed in multiple human cancers $[60,61]$. Its downregulation in the transfected Huh7 cells could contribute to the observed decrease in cell proliferation in the presence of $H$. bilis, and also suggested nontumourigenic effects of $H$. bilis. The binding protein, MM1 is a pre-folding protein that binds to newly synthesized cellular myelocytomatosis oncoprotein (C-MYC), stabilizing and allowing it to fold correctly [62]. Its downregulation by the transfected Huh7 cells suggested that C-MYC too may be downregulated further indicating a non-tumourigenic effect of H.bilis.

In the cured Huh7 cell line, GDI, HDGF and PHB were upregulated, and NPM and DJ-1 were downregulated. GDI belongs to the family of Rho GDP dissociation inhibitors that include RhoGDI, D4-GDI, and RhoGDI-3 [63]. They regulate the reorganization of the actin cytoskeleton and the integrity of associated integrin adhesion complexes [63]. GDI is expressed ubiquitously and is directly involved in cell adhesion. In breast cancer tissue, upregulation of GDI has been linked to the induction of Raf-1, a protein serine-threonine kinase, which plays a role in cell growth, proliferation, and cell survival [64]. Thus, the upregulation of GDI could be a tumourigenic response of the cured Huh7 cell line to $H$. bilis. HDGF is an acidic heparin-binding protein originally isolated from the cultured media of the Huh7 cell line [65]. It is expressed ubiquitously in normal tissue and in tumour cell lines [66, 67]. The protein has mitogenic effect because recombinant HDGF has been shown to stimulate the growth of a variety of cells including hepatoma cells $[65,68,69]$. Studies have indicated that HDGF participates in cellular proliferation and differentiation $[66,70]$, and its increased expression has been associated with poorly differentiated HCC cell lines and tumour progression in HCC specimens where it is thought to enhance the unregulated growth or recurrence of hepatoma cells [71]. The downregulation of HDGF by the cured Huh7 cells in cocultures with $H$. bilis therefore did not indicate a cancer-promoting response of the cell line to the presence of the bacterium.

Prohibitin-PHB is localized in the mitochondria, is essential for normal mitochondrial development, and plays a role in tumour suppression, proliferation, cell-cycle progression, and apoptosis [72]. PHB also co-localises with retinoblastoma protein $(\mathrm{pRb})$ and $\mathrm{P} 53$, which are known tumour suppressor proteins, and interacts with the transcription factor E2F in various cell lines [73, 74]. These observations indicate that $\mathrm{PHB}$ blocks cell proliferation and acts as tumour suppressor by cell-cycle arrest via the repression of E2F-mediated transcription [72, 75]. Dysregulation of $\mathrm{PHB}$ has not been documented in HCC, but its upregulated expression has been reported in other human cancer tissues and cell lines [76, 77]. The upregulation of PHB suggested a tumour-suppression effect of $H$. bilis on the cured Huh7 cell line, and could account for the decrease of Huh7 cells proliferation in the presence of the bacterium.

Many studies have suggested that NPM may be involved in cancer pathogenesis [78], however, its physiological function in tumourigenesis is still controversial since this protein has been ascribed both tumour suppressive and oncogenic functions [78]. Its downregulation in cured Huh7 cells would reflect a cancer-promoting effect of the bacterium. Functionally, DJ-1 has been implicated in fertilization [79], the regulation of androgen receptor signaling [80], and oxidative stress [81]. In addition, DJ-1 is involved in apoptosis [82] and cancer [83]. Its role in cancer is thought to involve the suppression of the tumour suppressor PTEN which in turn affects the function of the protein kinase $\mathrm{B}$ (PKB/AKT), a survival kinase [84]. The downregulation of DJ-1 would enhance the suppression of PKB/AKT by PTEN leading to a decrease in cell survival, a phenomenon that may help to explain the observed reduction in cell proliferation of the cured Huh7 cells in the presence of $H$. bilis and suggest a nontumourigenic effect of the bacterium on the cured hepatoma cell line.

Additional investigations of the potential tumourigenic effect of $H$. bilis on the transfected-and cured Huh7 cell lines were carried out by studying the differential expression of 16 HCC-related genes employing qRT-PCR (Figure 3).

Overall, the changes in the transcription of these HCCrelated genes differed between transfected- and cured Huh7 cells exposed to $H$. bilis. The genes $B A X$ and MCL-1 were downregulated in the transfected Huh7 cells but were upregulated in the cured Huh7 cells in the presence of $H$. bilis. Both genes belong to the B-cell lymphoma 2 family of apoptotic proteins, $B A X$ is proapoptotic while $M C L-1$ is antiapoptotic, and their dysregulation has been associated with HCC $[85,86]$. The downregulation of $B A X$ in the transfected Huh7 cells would enhance cell survival; in contrast, the downregulation of $M C L-1$ would enhance cell death. On the other hand, the upregulation of $B A X$ and MCL-1 by the cured Huh7 cells would enhance cell death and cell survival, respectively. Thus, the modulation of the expression of these two genes suggested a complex regulation of apoptosis in response to the presence of $H$. bilis which was different in both types of cells. 


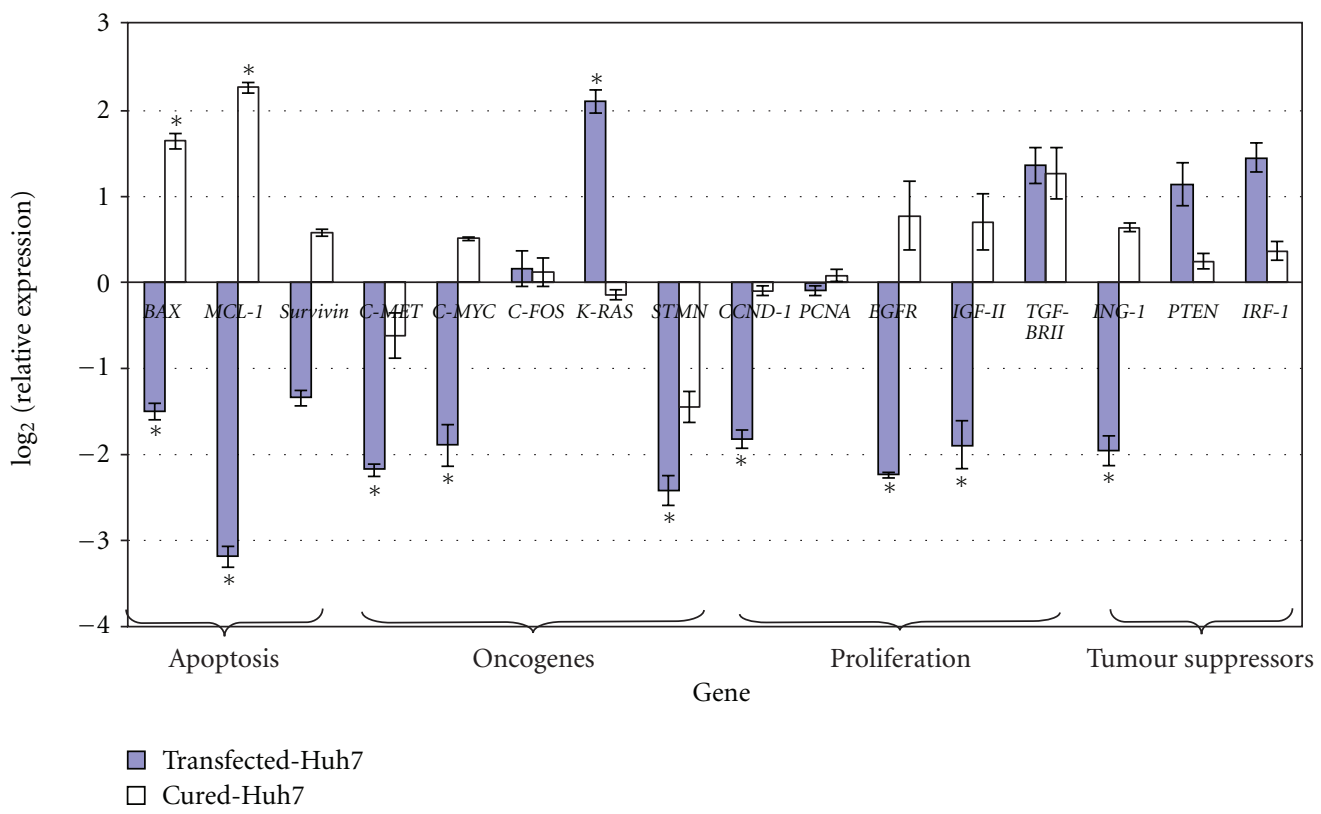

Figure 3: Relative expression of HCC-related genes in transfected- \& cured Huh7 cells in response to H. bilis. Values are presented as log 2 of the relative expression and represent the mean relative expression derived from biological triplicates. ${ }^{*} P<0.05$.

The oncogene KI-RAS was upregulated while C-MET, $C-M Y C$, and STMN were downregulated by the transfected Huh7 cells. KI-RAS belongs to the RAS family of GTP-binding proteins and signals through the RAS/RAF/ MEK/ERK pathway to activate the downstream transcription factors including NK- $\kappa \mathrm{B}, \mathrm{CREB}, \mathrm{AP}-1$, and C-MYC [87], all of which have roles in regulating proliferation and apoptosis [88]. C-MET is a hepatocyte growth factor receptor encoding tyrosine-kinase activity. C-MET also signals via the RAS/RAF/MEK/ERK as well as the P13/AKT/PTEN pathways [89]. In HCC, C-MET is an essential factor in the process of migration and invasion of hepatocarcinoma cells [90]. Thus, the downregulation of these effector oncogenes, regardless of the upregulation of KI-RAS, is consistent with the proposition that $H$. bilis promoted anticancer activity in the transfected Huh7 cells.

The cell proliferation regulators CCND-1, EGFR and IGF-II were downregulated in the transfected Huh7 cells. EGFR is a receptor for the transforming growth factor alpha (TGF- $\alpha$ ), a mitogenic growth factor required to trigger the proliferative state. Expression of EGFR is associated with HCC [91]; its inhibition induces growth arrest and apoptosis in HCC cell lines [92] and prevents HCC development in rats [93]. Thus, its downregulation would promote the cell death of the transfected Huh7 cells. In addition, EGFR together with IGF-II signal through the P13K/AKT/PTEN and RAS/RAF/MEK/ERK pathways and promote the downstream activation of genes including the CCND1, thus, the downregulation of EGFR and IGF-II suggested an antitumour response by the human cells and correlated with the downregulation of CCND1 by the transfected Huh7 cells in response to $H$. bilis. CCND1 acts in concert with cyclin-dependent kinase to phosphorylate and activate the retinoblastoma protein $(\mathrm{pRB})$, which is involved in cell proliferation. Upregulation of CCND1 has been reported in human and mice HCC tissues [94], thus, its downregulation suggested also a nontumourigenic effect of $H$. bilis on the transfected Huh7 cells. In contrast, the downregulation of the tumour suppressor gene ING1, whose product is a nuclear protein that physically interacts with the tumor suppressor protein TP53 in the p53-signaling pathway [95], and can induce cell growth arrest and apoptosis, suggested a tumourigenic effects of $H$. bilis on the transfected Huh7 cells.

\section{Conclusion}

Taken together, the differential expression of some tumourrelated proteins and $\mathrm{HCC}$-associated genes provided evidence for the carcinogenic effects of $\mathrm{H}$. bilis on the Huh7derived cell lines, although the expression pattern of other proteins and genes did not support this conclusion. This apparent contradiction may be explained by the fact that hepatocarcinogenesis involves multiple factors and pathways and are dependent on the carcinogen. Thus, it is possible that Helicobacter spp. could initiate dysplasia in hepatocytes through several processes some of which may not involve known classical pathways in HCC development. The result further shows that $H$. bilis exerted multiple stresses on both the transfected and cured Huh7 cell lines, which appeared to have affected the function of the mitochondria and endoplasmic reticulum. At the molecular level, the transfected Huh7 cell line expressed genes which indicated that the cell line was more susceptible to the effect of the bacterium than to the cured Huh7 cell line. Thus, it is possible that $H$. bilis could potentiate the development from dysplasia to neoplasia of the liver cells in the background of HCV-infection. The similarities between the transfected and cured Huh7 cell lines in the modulation of proteins belonging to biological 
functional categories, some of which are implicated in cell necrosis, revealed some common response of both cell lines to the presence of $H$. bilis regardless of the presence of the HCV-replicon in the transfected-cells, and suggested that the bacterium could initiate preneoplastic processes in these cell lines.

\section{Conflict of Interests}

The authors declare that there are no financial or any other conflict interests.

\section{Acknowledgments}

This study was supported by the Australian Research Council. Dr. A. S. Okoli is a lecturer at the University of Nigeria, Nsukka, Nigeria; he is currently on postdoctoral fellowship at GenØK-Centre for Biosafety. He also acknowledges receipt of the Endeavour International Postgraduate Research Scholarship.

\section{References}

[1] M. G. Peters and N. A. Terrault, "Alcohol use and hepatitis C," Hepatology, vol. 36, no. 5, supplement 1, pp. S220-S225, 2002.

[2] M. C. Kew, "Synergistic interaction between aflatoxin B1 and hepatitis B virus in hepatocarcinogenesis," Liver International, vol. 23, no. 6, pp. 405-409, 2003.

[3] M. C. Kew, "Interaction between hepatitis B and C viruses in hepatocellular carcinogenesis," Journal of Viral Hepatitis, vol. 13, no. 3, pp. 145-149, 2006.

[4] A. Ponzetto, R. Pellicano, N. Leone et al., "Helicobacter infection and cirrhosis in hepatitis $\mathrm{C}$ virus carriage: is it an innocent bystander or a troublemaker?" Medical Hypotheses, vol. 54, no. 2, pp. 275-277, 2000.

[5] X. G. Fan, X. N. Peng, Y. Huang, J. Yakoob, Z. M. Wang, and Y. P. Chen, "Helicobacter species ribosomal DNA recovered from the liver tissue of chinese patients with primary hepatocellular carcinoma," Clinical Infectious Diseases, vol. 35, no. 12, pp. 1555-1557, 2002.

[6] S. R. Boutin, A. B. Rogers, Z. Shen et al., "Hepatic temporal gene expression profiling in Helicobacter hepaticus-infected A/JCr mice," Toxicologic Pathology, vol. 32, no. 6, pp. 678-693, 2004.

[7] K. Ito, M. Nakamura, G. Toda, M. Negishi, A. Torii, and T. Ohno, "Potential role of Helicobacter pylori in hepatocarcinogenesis," International Journal of Molecular Medicine, vol. 13, no. 2, pp. 221-227, 2004.

[8] M. Rocha, P. Avenaud, A. Ménard et al., "Association of Helicobacter species with hepatitis C cirrhosis with or without hepatocellular carcinoma," Gut, vol. 54, no. 3, pp. 396-401, 2005.

[9] T. G. Blanchard, "Host response and vaccine development to Helicobacter pylori infection," Current Topics in Microbiology and Immunology, vol. 241, pp. 181-213, 1999.

[10] A. B. Rogers and J. G. Fox, "Inflammation and cancer: I. Rodent models of infectious gastrointestinal and liver cancer," American Journal of Physiology, vol. 286, no. 3, pp. G361G366, 2004.

[11] T. L. Fong, A. M. Di Bisceglie, J. G. Waggoner, S. M. Banks, and J. H. Hoofnagle, "The significance of antibody to hepatitis
C virus in patients with chronic hepatitis B," Hepatology, vol. 14 , no. 1, pp. 64-67, 1991.

[12] J. F. Tsai, J. E. Jeng, M. S. Ho, W. Y. Chang, Z. Y. Lin, and J. H. Tsai, "Independent and additive effect modification of hepatitis $\mathrm{C}$ and $\mathrm{B}$ viruses infection on the development of chronic hepatitis," Journal of Hepatology, vol. 24, no. 3, pp. 271-276, 1996.

[13] J. M. Ward, J. G. Fox, M. R. Anver et al., "Chronic active hepatitis and associated liver tumors in mice caused by a persistent bacterial infection with a novel Helicobacter species," Journal of the National Cancer Institute, vol. 86, no. 16, pp. 1222-1227, 1994.

[14] J. G. Fox, F. E. Dewhirst, J. G. Tully et al., "Helicobacter hepaticus sp. nov., a microaerophilic bacterium isolated from livers and intestinal mucosal scrapings from mice," Journal of Clinical Microbiology, vol. 32, no. 5, pp. 1238-1245, 1994.

[15] IARC, "Working group on the evaluation of carcinogenic risks to humans Helicobacter pylori," IARC Monogr Eval Carcinog Risks Hum, vol. 61, IARC:Lyon, 1994.

[16] J. G. Fox, L. L. Yan, F. E. Dewhirst et al., "Helicobacter bilis sp. nov., a novel Helicobacter species isolated from bile, livers, and intestines of aged, inbred mice," Journal of Clinical Microbiology, vol. 33, no. 2, pp. 445-454, 1995.

[17] J. G. Fox, A. B. Rogers, M. T. Whary et al., "Helicobacter bilisassociated hepatitis in outbred mice," Comparative Medicine, vol. 54, no. 5, pp. 571-577, 2004.

[18] H. Nakabayashi, K. Taketa, and K. Miyano, "Growth of human hepatoma cell lines with differentiated functions in chemically defined medium," Cancer Research, vol. 42, no. 9, pp. 38583863, 1982.

[19] G. Li et al., "Cancer: a proteomic disease," Science China Life Sciences, vol. 54, no. 5, pp. 403-408, 2011.

[20] G. Q. Geng, P. F. Zhang, X. Deng et al., "Identification of novel biomarkers for early detection of human lung squamous cell cancer by quantitative proteomics," Molecular \& Cellular Proteomics, vol. 11, no. 6, 2012.

[21] Y. Inoue, K. Murakami, S. S. Hmwe, H. Aizaki, and T. Suzuki, "Transcriptomic comparison of human hepatoma HuH-7 cell clones with different hepatitis C virus replication efficiences," Japanese Journal of Infectious Diseases, vol. 60, no. 4, pp. 173178, 2007.

[22] M. Ikeda, M. Yi, K. Li, and S. M. Lemon, "Selectable subgenomic and genome-length dicistronic RNAs derived from an infectious molecular clone of the HCV-N strain of hepatitis C virus replicate efficiently in cultured Huh7 cells," Journal of Virology, vol. 76, no. 6, pp. 2997-3006, 2002.

[23] A. S. Okoli, E. M. Fox, M. J. Raftery, and G. L. Mendz, "Effects of Helicobacter hepaticus on the proteome of HEp-2 cells," Antonie van Leeuwenhoek, vol. 92, no. 3, pp. 289-300, 2007.

[24] T. Rabilloud, L. Vuillard, C. Gilly, and J. J. Lawrence, "Silverstaining of proteins in polyacrylamide gels: a general overview," Cellular and Molecular Biology, vol. 40, no. 1, pp. 5775, 1994.

[25] M. W. Pfaffl, G. W. Horgan, and L. Dempfle, "Relative expression software tool (REST) for group-wise comparison and statistical analysis of relative expression results in real-time PCR," Nucleic Acids Research, vol. 30, no. 9, pp. 1-10, 2002.

[26] K. J. Livak and T. D. Schmittgen, "Analysis of relative gene expression data using real-time quantitative PCR and the 2$\Delta \Delta$ CT method," Methods, vol. 25, no. 4, pp. 402-408, 2001.

[27] D. L. Diamond, A. J. Syder, J. M. Jacobs et al., "Temporal proteome and lipidome profiles reveal hepatitis C virusassociated reprogramming of hepatocellular metabolism and 
bioenergetics," PLoS Pathogens, vol. 6, no. 1, Article ID e1000719, 2010.

[28] M. Ikeda and N. Kato, "Modulation of host metabolism as a target of new antivirals," Advanced Drug Delivery Reviews, vol. 59, no. 12, pp. 1277-1289, 2007.

[29] V. O. Palmieri, I. Grattagliano, P. Portincasa, and G. Palasciano, "Systemic oxidative alterations are associated with visceral adiposity and liver steatosis in patients with metabolic syndrome," Journal of Nutrition, vol. 136, no. 12, pp. 3022 3026, 2006.

[30] Y. Nishimura-Sakurai, N. Sakamoto, K. Mogushi et al., "Comparison of $\mathrm{HCV}$-associated gene expression and cell signaling pathways in cells with or without HCV replicon and in replicon-cured cells," Journal of Gastroenterology, vol. 45, no. 5, pp. 523-536, 2010.

[31] B. A. Freeman and J. D. Crapo, "Biology of disease. Free radicals and tissue injury," Laboratory Investigation, vol. 47, no. 5, pp. 412-426, 1982.

[32] F. Kageyama, Y. Kobayashi, T. Kawasaki, S. Toyokuni, K. Uchida, and H. Nakamura, "Successful interferon therapy reverses enhanced hepatic iron accumulation and lipid peroxidation in chronic hepatitis C," American Journal of Gastroenterology, vol. 95, no. 4, pp. 1041-1050, 2000.

[33] K. Machida, K. T. N. Cheng, V. M. H. Sung et al., "Hepatitis $\mathrm{C}$ virus induces a mutator phenotype: enhanced mutations of immunoglobulin and protooncogenes," Proceedings of the National Academy of Sciences of the United States of America, vol. 101, no. 12, pp. 4262-4267, 2004.

[34] K. Machida, K. T. H. Cheng, V. M. H. Sung, K. J. Lee, A. M. Levine, and M. M. C. Lai, "Hepatitis $\mathrm{C}$ virus infection activates the immunologic (type II) isoform of nitric oxide synthase and thereby enhances DNA damage and mutations of cellular genes," Journal of Virology, vol. 78, no. 16, pp. 8835-8843, 2004.

[35] M. A. D. Siepen, C. Oniangue-Ndza, M. Wiese, S. Ross, M. Roggendorf, and S. Viazov, "Interferon- $\alpha$ and ribavirin resistance of Huh7 cells transfected with HCV subgenomic replicon," Virus Research, vol. 125, no. 1, pp. 109-113, 2007.

[36] H. Zhu, D. R. Nelson, J. M. Crawford, and C. Liu, "Defective Jak-Stat activation in hepatoma cells is associated with hepatitis C viral IFN- $\alpha$ resistance," Journal of Interferon and Cytokine Research, vol. 25, no. 9, pp. 528-539, 2005.

[37] J. E. Chipuk, T. Kuwana, L. Bouchier-Hayes et al., "Direct activation of Bax by p53 mediates mitochondrial membrane permeabilization and apoptosis," Science, vol. 303, no. 5660, pp. 1010-1014, 2004.

[38] E. Brockstedt, A. Rickers, S. Kostka et al., "Identification of apoptosis-associated proteins in a human Burkitt lymphoma cell line: cleavage of heterogeneous nuclear ribonucleoprotein A1 by caspase 3," Journal of Biological Chemistry, vol. 273, no. 43, pp. 28057-28064, 1998.

[39] K. P. Bhat, K. Itahana, A. Jin, and Y. Zhang, "Essential role of ribosomal protein L11 in mediating growth inhibitioninduced p53 activation," EMBO Journal, vol. 23, no. 12, pp. 2402-2412, 2004.

[40] M. S. Dai and H. Lu, "Inhibition of MDM2-mediated p53 ubiquitination and degradation by ribosomal protein L5," Journal of Biological Chemistry, vol. 279, no. 43, pp. 4447544482, 2004.

[41] D. Tedesco, J. Zhang, L. Trinh et al., "The ubiquitin-conjugating enzyme E2-EPF is overexpressed in primary breast cancer and modulates sensitivity to topoisomerase II inhibition," Neoplasia, vol. 9, no. 7, pp. 601-613, 2007.
[42] R. M. Hofmann and C. M. Pickart, "Noncanonical MMS2encoded ubiquitin-conjugating enzyme functions in assembly of novel polyubiquitin chains for DNA repair," Cell, vol. 96, no. 5, pp. 645-653, 1999.

[43] P. Benes, V. Vetvicka, and M. Fusek, "Cathepsin D-Many functions of one aspartic protease," Critical Reviews in Oncology/Hematology, vol. 68, no. 1, pp. 12-28, 2008.

[44] G. Leto, F. M. Tumminello, G. Pizzolanti et al., "Cathepsin D serum mass concentrations in patients with hepatocellular carcinoma and/or liver cirrhosis," European Journal of Clinical Chemistry and Clinical Biochemistry, vol. 34, no. 7, pp. 555560, 1996.

[45] L. Hu, S. H. Lau, C. H. Tzang et al., "Association of Vimentin overexpression and hepatocellular carcinoma metastasis," Oncogene, vol. 23, no. 1, pp. 298-302, 2004.

[46] C. Gilles, M. Polette, J. M. Zahm et al., "Vimentin contributes to human mammary epithelial cell migration," Journal of Cell Science, vol. 112, part 24, pp. 4615-4625, 1999.

[47] A. Ben-Ze'ev and A. Raz, "Relationship between the organization and synthesis of vimentin and the metastatic capability of B16 melanoma cells," Cancer Research, vol. 45, no. 6, pp. 2632-2641, 1985.

[48] W. Domagala, G. Striker, A. Szadowska, A. Dukowicz, B. Harezga, and M. Osborn, "p53 protein and vimentin in invasive ductal NOS breast carcinoma-relationship with survival and sites of metastases," European Journal of Cancer Part A, vol. 30, no. 10, pp. 1527-1534, 1994.

[49] M. J. C. Hendrix, E. A. Seftor, R. E. B. Seftor, and K. T. Trevor, "Experimental co-expression of vimentin and keratin intermediate filaments in human breast cancer cells results in phenotypic interconversion and increased invasive behavior," American Journal of Pathology, vol. 150, no. 2, pp. 483-495, 1997.

[50] H. Iwatsuki, K. Sasaki, M. Suda, and C. Itano, "Vimentin intermediate filament protein as differentiation marker of optic vesicle epithelium in the chick embryo," Acta Histochemica, vol. 101, no. 4, pp. 369-382, 1999.

[51] S. Waxman and E. Wurmbach, "De-regulation of common housekeeping genes in hepatocellular carcinoma," BMC genomics, vol. 8, p. 243, 2007.

[52] A. H. Khimani, A. M. Mhashilkar, A. Mikulskis et al., "Housekeeping genes in cancer: normalization of array data," BioTechniques, vol. 38, no. 5, pp. 739-745, 2005.

[53] J. B. de Kok, R. W. Roelofs, B. A. Giesendorf et al., "Normalization of gene expression measurements in tumor tissues: comparison of 13 endogenous control genes," Laboratory Investigation, vol. 85, no. 1, pp. 154-159, 2005.

[54] N. Esen, D. Shuffield, M. M. Syed, and T. Kielian, "Modulation of connexin expression and gap junction communication in astrocytes by the gram-positive bacterium S. aureus," GLIA, vol. 55, no. 1, pp. 104-117, 2007.

[55] J. Mathur, N. Mathur, V. Kirik, B. Kernebeck, B. P. Srinivas, and M. Hülskamp, "Arabidopsis crooked encodes for the smallest subunit of the ARP2/3 complex and controls cell shape by region specific fine F-actin formation," Development, vol. 130, no. 14, pp. 3137-3146, 2003.

[56] K. Dejgaard, H. Leffers, H. H. Rasmussen et al., "Identification, molecular cloning, expression and chromosome mapping of a family of transformation upregulated hnRNP-K proteins derived by alternative splicing," Journal of Molecular Biology, vol. 236, no. 1, pp. 33-48, 1994.

[57] J. A. Byrne, C. R. Nourse, P. Basset, and P. Gunning, "Identification of homo- and heteromeric interactions between members of the breast carcinoma-associated D52 protein 
family using the yeast two-hybrid system," Oncogene, vol. 16, no. 7, pp. 873-881, 1998.

[58] J. A. Byrne, M. G. Mattei, and P. Basset, "Definition of the tumor protein D52 (TPD52) gene family through cloning of D52 homologues in human (hD53) and mouse (mD52)," Genomics, vol. 35, no. 3, pp. 523-532, 1996.

[59] T. Grewal, S. Enrich, and S. Jackle, "Role of annexin 6 in receptor-mediated endocytosis, membrane trafficking and signal transduction," in Annexins: Biological Importance and Annexin-Related Pathologies, J. Bandorowicz-Pikula, Ed., chaper 11, Kluwer Academic/Plenum Publishers, New York, NY, USA, 2003.

[60] J. A. Byrne, C. Tomasetto, J. M. Garnier et al., "A screening method to identify genes commonly overexpressed in carcinomas and the identification of a novel complementary DNA sequence," Cancer Research, vol. 55, no. 13, pp. 2896-2903, 1995.

[61] S. L. Chen, I. G. Maroulakou, J. E. Green et al., "Isolation and characterization of a novel gene expressed in multiple cancers," Oncogene, vol. 12, no. 4, pp. 741-751, 1996.

[62] K. Mori, Y. Maeda, H. Kitaura, T. Taira, S. M. M. Iguchi-Ariga, and $\mathrm{H}$. Ariga, "MM-1, a novel c-Myc-associating protein that represses transcriptional activity of c-Myc," Journal of Biological Chemistry, vol. 273, no. 45, pp. 29794-29800, 1998.

[63] C. DerMardirossian and G. M. Bokoch, "GDIs: central regulatory molecules in Rho GTPase activation," Trends in Cell Biology, vol. 15, no. 7, pp. 356-363, 2005.

[64] H. Ishizaki, A. Togawa, M. Tanaka-Okamoto et al., "Defective chemokine-directed lymphocyte migration and development in the absence of Rho guanosine diphosphate-dissociation inhibitors $\alpha$ and $\beta$," Journal of Immunology, vol. 177, no. 12, pp. 8512-8521, 2006.

[65] H. Nakamura, H. Kambe, T. Egawa et al., "Partial purification and characterization of human hepatoma-derived growth factor," Clinica Chimica Acta, vol. 183, no. 3, pp. 273-284, 1989.

[66] A. D. Everett, "Identification, cloning, and developmental expression of hepatoma-derived growth factor in the developing rat heart," Developmental Dynamics, vol. 222, no. 3, pp. 450-458, 2001.

[67] S. Wanschura, E. F. P. M. Schoenmakers, C. Huysmans, S. Bartnitzke, W. J. M. van de Ven, and J. Bullerdiek, "Mapping of the human HM G2 gene to 4q31," Genomics, vol. 31, no. 2, pp. 264-265, 1996.

[68] A. D. Everett, D. R. Lobe, M. E. Matsumura, H. Nakamura, and C. A. McNamara, "Hepatoma-derived growth factor stimulates smooth muscle cell growth and is expressed in vascular development," Journal of Clinical Investigation, vol. 105, no. 5, pp. $567-575,2000$.

[69] J. A. Oliver and Q. Ai-Awqati, "An endothelial growth factor involved in rat renal development," Journal of Clinical Investigation, vol. 102, no. 6, pp. 1208-1219, 1998.

[70] K. L. Crossin, M. H. Tai, L. A. Krushel, V. P. Mauro, and G. M. Edelman, "Glucocorticoid receptor pathways are involved in the inhibition of astrocyte proliferation," Proceedings of the National Academy of Sciences of the United States of America, vol. 94, no. 6, pp. 2687-2692, 1997.

[71] T. H. Hu, C. C. Huang, L. F. Liu et al., "Expression of hepatoma-derived growth factor in hepatocellular carcinoma: a novel prognostic factor," Cancer, vol. 98, no. 7, pp. 1444-1456, 2003.

[72] S. Mishra, L. C. Murphy, B. L. G. Nyomba, and L. J. Murphy, "Prohibitin: a potential target for new therapeutics," Trends in Molecular Medicine, vol. 11, no. 4, pp. 192-197, 2005.
[73] M. J. Nuell, D. A. Stewart, L. Walker et al., "Prohibitin, an evolutionarily conserved intracellular protein that blocks DNA synthesis in normal fibroblasts and HeLa cells," Molecular and Cellular Biology, vol. 11, no. 3, pp. 1372-1381, 1991.

[74] J. K. Mcclung, E. R. Jupe, X. T. Liu, and R. T. Dell'Orco, "Prohibitin: potential role in senescence, development, and tumor suppression," Experimental Gerontology, vol. 30, no. 2, pp. 99-124, 1995.

[75] E. R. Jupe, X. T. Liu, J. L. Kiehlbauch, J. K. McClung, and R. T. Dell'Orco, "Prohibitin antiproliferative activity and lack of heterozygosity in immortalized cell lines," Experimental Cell Research, vol. 218, no. 2, pp. 577-580, 1995.

[76] A. Jakubowska, J. Gronwald, J. Menkiszak et al., "Ovarian cancer risk in Polish BRCA1 mutation carriers is not associated with the prohibitin $3^{\prime}$ untranslated region polymorphism," BMC Cancer, vol. 8, article 90, 2008.

[77] T. K. Seow et al., "Two-dimensional electrophoresis map of the human hepatocellular carcinoma cell line, HCC-M and identification of the separated proteins by mass spectrometry," Electrophoresis, vol. 21, no. 9, pp. 1787-1813, 2000.

[78] M. J. Lim and X. W. Wang, "Nucleophosmin and human cancer," Cancer Detection and Prevention, vol. 30, no. 6, pp. 481-490, 2006.

[79] M. Okada, K. I. Matsumoto, T. Niki, T. Taira, S. M. M. IguchiAriga, and H. Ariga, "DJ-1, a target protein for an endocrine disrupter, participates in the fertilization in mice," Biological and Pharmaceutical Bulletin, vol. 25, no. 7, pp. 853-856, 2002.

[80] T. Niki, K. Takahashi-Niki, T. Taira, S. M. M. Iguchi-Ariga, and H. Ariga, "DJBP: a novel DJ-1-binding protein, negatively regulates the androgen receptor by recruiting histone deacetylase complex, and DJ-1 antagonizes this inhibition by abrogation of this complex," Molecular Cancer Research, vol. 1, no. 4, pp. 247-261, 2003.

[81] R. M. Canet-Avilés, M. A. Wilson, D. W. Miller et al., "The Parkinson's disease DJ-1 is neuroprotective due to cysteinesulfinic acid-driven mitochondrial localization," Proceedings of the National Academy of Sciences of the United States of America, vol. 101, no. 24, pp. 9103-9108, 2004.

[82] Y. Hod, "Differential control of apoptosis by DJ-1 in prostate benign and cancer cells," Journal of Cellular Biochemistry, vol. 92, no. 6, pp. 1221-1233, 2004.

[83] J. P. MacKeigan, C. M. Clements, J. D. Lich, R. M. Pope, Y. Hod, and J. P. Y. Ting, "Proteomic profiling drug-induced apoptosis in non-small cell lung carcinoma: identification of RS/DJ-1 and RhoGDI $\alpha$," Cancer Research, vol. 63, no. 20, pp. 6928-6934, 2003.

[84] T. Maehama and J. E. Dixon, "The tumor suppressor, PTEN/ MMAC1, dephosphorylates the lipid second messenger, phosphatidylinositol 3,4,5-trisphosphate," Journal of Biological Chemistry, vol. 273, no. 22, pp. 13375-13378, 1998.

[85] X. Z. Guo, X. D. Shao, M. P. Liu et al., "Effect of bax, bcl-2 and bcl-xL on regulating apoptosis in tissues of normal liver and hepatocellular carcinoma," World Journal of Gastroenterology, vol. 8, no. 6, pp. 1059-1062, 2002.

[86] B. Fleischer, H. Schulze-Bergkamen, M. Schuchmann et al., "Mcl-1 is an anti-apoptotic factor for human hepatocellular carcinoma," International Journal of Oncology, vol. 28, no. 1, pp. 25-32, 2006.

[87] L. C. Wang, W. Vass, C. Gao, and K. S. S. Chang, "Amplification and enhanced expression of the c-Ki-ras2 protooncogene in human embryonal carcinomas," Cancer Research, vol. 47, no. 15, pp. 4192-4198, 1987.

[88] F. Chang, L. S. Steelman, J. T. Lee et al., "Signal transduction mediated by the Ras/Raf/MEK/ERK pathway from cytokine 
receptors to transcription factors: potential targeting for therapeutic intervention," Leukemia, vol. 17, no. 7, pp. 12631293, 2003.

[89] D. Tulasne and B. Foveau, "The shadow of death on the MET tyrosine kinase receptor," Cell Death and Differentiation, vol. 15, no. 3, pp. 427-434, 2008.

[90] A. Salvi, B. Arici, N. Portolani, S. M. Giulini, G. de Petro, and S. Barlati, "In vitro c-met inhibition by antisense RNA and plasmid-based RNAi down-modulates migration and invasion of hepatocellular carcinoma cells," International Journal of Oncology, vol. 31, no. 2, pp. 451-460, 2007.

[91] Y. H. Chung et al., "Expression of transforming growth factoralpha mRNA in livers of patients with chronic viral hepatitis and hepatocellular carcinoma," Cancer, vol. 89, no. 5, pp. 977$982,2000$.

[92] M. Höpfner, A. P. Sutter, A. Huether, D. Schuppan, M. Zeitz, and H. Scherübl, "Targeting the epidermal growth factor receptor by gefitinib for treatment of hepatocellular carcinoma," Journal of Hepatology, vol. 41, no. 6, pp. 1008-1016, 2004.

[93] E. Schiffer, C. Housset, W. Cacheux et al., "Gefitinib, an EGFR inhibitor, prevents hepatocellular carcinoma development in the rat liver with cirrhosis," Hepatology, vol. 41, no. 2, pp. $307-$ 314, 2005.

[94] N. Nishida, Y. Fukuda, T. Komeda et al., "Amplification and overexpression of the cyclin D1 gene in aggressive human hepatocellular carcinoma," Cancer Research, vol. 54, no. 12, pp. 3107-3110, 1994.

[95] H. Kataoka, P. Bonnefin, D. Vieyra et al., "ING1 represses transcription by direct DNA binding and through effects on p53," Cancer Research, vol. 63, no. 18, pp. 5785-5792, 2003. 


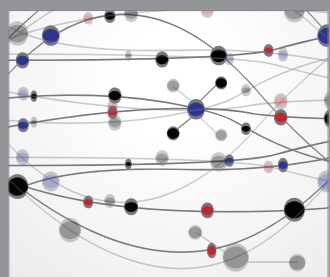

The Scientific World Journal
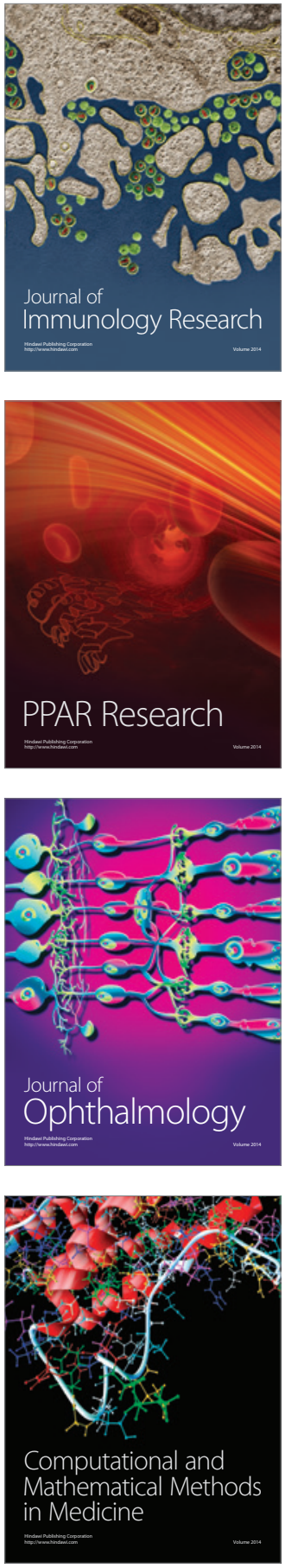

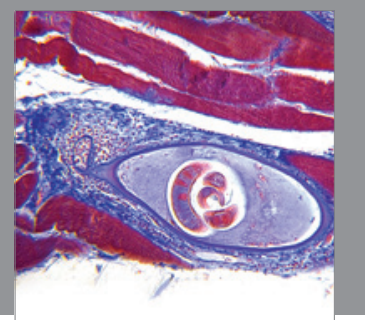

Gastroenterology

Research and Practice
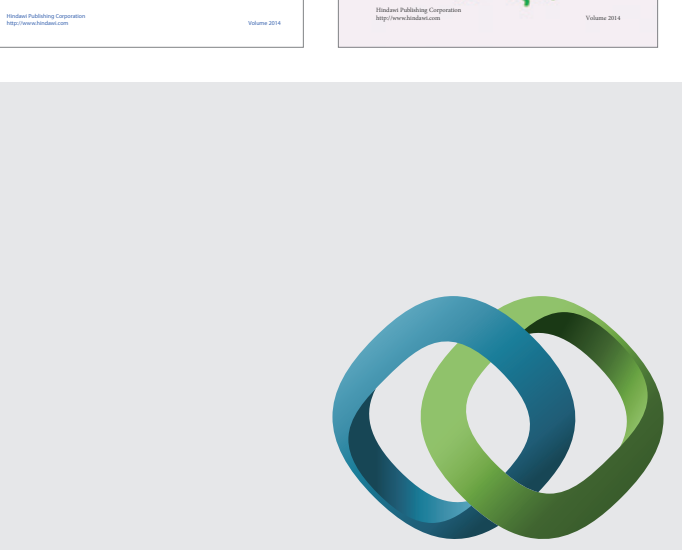

\section{Hindawi}

Submit your manuscripts at

http://www.hindawi.com
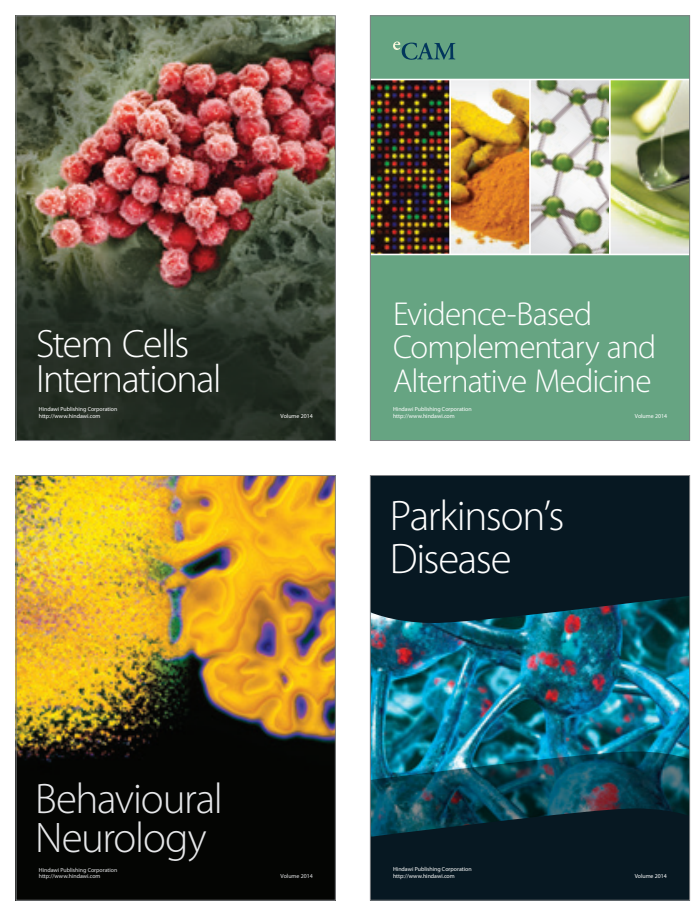

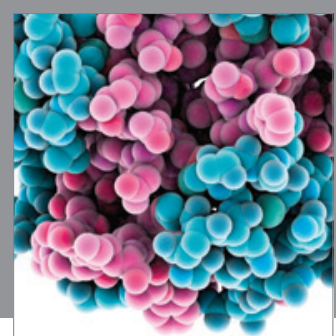

Journal of
Diabetes Research

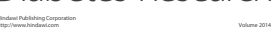

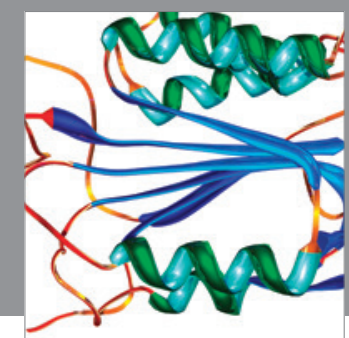

Disease Markers
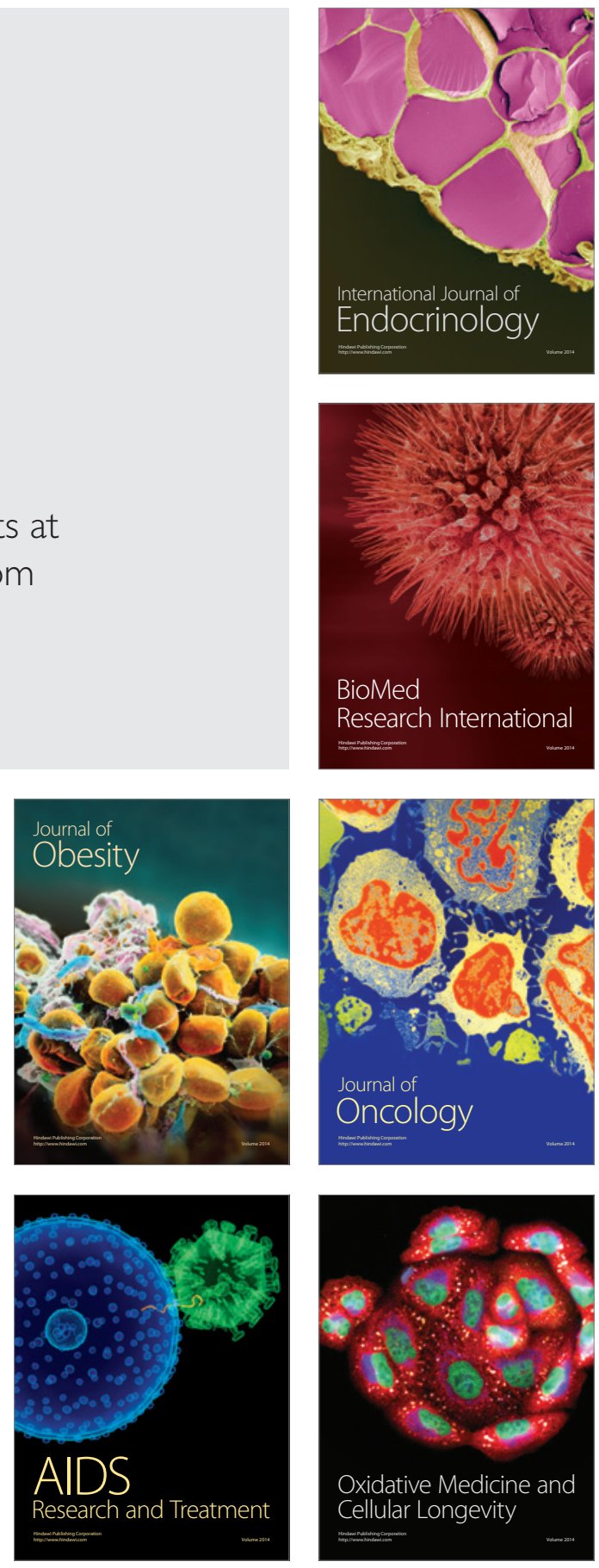